\title{
REAÇÃO DE PLANTAS CÍTRICAS À BACTÉRIA Xylella fastidiosa EM FUNÇÃO DE DIFERENTES MÉTODOS DE INOCULAÇÃO
}

\author{
ARIANE BUSCH SALIBE
}

Engenheira Agrônoma

Orientador: Prof. Dr. FRANCISCO DE ASSIS ALVES MOURÃO FILHO

Tese apresentada à Escola Superior de Agricultura "Luiz de Queiroz", Universidade de São Paulo, para obtenção do titulo de Doutor em Agronomia, Área de Concentração: Fitotecnia.

PIRACICABA

Estado de São Paulo - Brasil

Fevereiro - 2001 
ERRATA

\begin{tabular}{l} 
Onde se lê: \\
\hline inoculação com agulha de um concent \\
.....plantas cítricas afetadas são pouco \\
específicos e lembram..... \\
.......sendo que até o momento, não foi \\
observada..... \\
"pool" genético
\end{tabular}

12

Poncirus trifoliata

Gênero Poncirus trifoliata (L.)

uma polegada

....acelerou-se nos ultimos anos de forma

explosiva
Leia-se

inoculação com agulha entomológica de uma

suspensão

......plantas cítricas afetadas lembram.....

.......sendo que até 1993, não tinha sido

observada.....

germoplasma

13

Poncirus

Gênero Poncirus (L.)

$2,54 \mathrm{~cm}$

....acelerou-se a partir de 1993 de forma acentuada.......
Páginas Linhas

iii

2

2

2

3

3

4

7

9

12

6

.....São Paulo de 44\% em agosto de 1992 para $88 \%$ em maio de 1995 , e afirmaram que....

Recentemente, observou-se....

Observou-se....

inoculação

Sobrenxertados

Piracicaba-SP, 1999.

Piracicaba-SP, 1999/2000.

40

(Tabela 1)

A presença da bactéria nas variedades passou......

Avaliações-PCR (08/08/99 à 08/03/00)

$40 \quad 1$

(Tabela 2)

Piracicaba-SP, 1999/2000.

(Tabela 3)

Piracicaba-SP, 1999/2000.

46

(Tabela 4)

7. Entre plantas serologicamente positivas, a .....

7. Os testes PCR e ELISA foram adequados na deteç̧ão do patógeno.

inoculação

....e sintomáticas

Piracicaba-SP, 1999/2000.

...mostrou ser hospedeira da X. fastidiosa quando inoculada com suspensão bacteriana através de alfinete entomológico 
Dados Internacionais de Catalogaçāo na Publicaçāo (CIP) DIVISÃO DE BIBLIOTECA E DOCUMENTAÇÃO - Campus "Luiz de Queiroz"/USP

\author{
Salibe, Ariane Busch \\ Reação de plantas citricas à bactéria Xylella fastidiosa em função de diferentes métodos \\ de inoculação / Ariane Busch Salibe. - - Piracicaba, 2001. \\ $75 \mathrm{p}$. \\ Tese (doutorado) - Escola Superior de Agricultura Luiz de Queiroz, 2001. \\ Bibliografia. \\ 1. Bactéria fitopatogênica 2. Clorose-variegada-dos-citros 3. Doença bacteriana 4. Fruta \\ cítrica 5. Inoculaçāo 6. Inseto-vetor-de-doença-em-planta I. Título
}

CDD 634.3

"Permitida acópia total ou parcial destedocunento desde que citada a fonte $-O$ autor" 
À minha mãe e irmã,

pelo amor e compreensão.

Ao meu marido

pela dedicação, amor e apoio.

Ao meu filho que vai nascer

que é fruto de um grande amor,

a minha homenagem.

A DEUS,

pela vida e por tudo,

Agradeço.

Ao meu pai, Ary A. Salibe, pelo constante apoio em todos os momentos, estímulo e compreensão, Dedico 


\section{AGRADECIMENTOS}

Ao Prof. Dr. Francisco de Assis Alves Mourão Filho, pela competente orientação, constante disponibilidade, por sua amizade, apoio, confiança e estímulo à minha formação profissional;

Ao Dr. Marcos Antônio Machado, do Centro de Citricultura 'Sylvio Moreira"/ IAC, pelo apoio, contribuição na orientação e por ter cedido as instalações do laboratório, nas quais foi realizada parte das análises e avaliações do trabalho;

Ao Prof. Dr. Keigo Minami, pelo apoio e orientação prestada;

À Escola Superior de Agricultura "Luiz de Queiroz" e ao Departamento de Produção Vegetal, pela oportunidade de realização do curso;

À FAPESP - Fundação de Amparo à Pesquisa do Estado de São Paulo, pela bolsa de estudos e financiamento do projeto.

Ao FUNDECITRUS - Fundo Paulista de Defesa da Citricultura, pela colaboração prestada.

Ao Centro de Citricultura "Sylvio Moreira"/IAC, pelos laboratórios de Biotecnologia Molecular e Clínica Fitopatológica, além de outras dependências que foram utilizadas para a execução da tese;

Aos colegas e funcionários do CCSM/IAC e da ESALQ/USP, pela colaboração prestada; 
Aos funcionários da Biblioteca Central da ESALQ, pela grande colaboração prestada; Ao Prof. José Celso Soares Vieira, pela correção gramatical da tese; A todos os amigos que, direta ou indiretamente, colaboraram com apoio e amizade. 


\section{SUMÁRIO}

Página

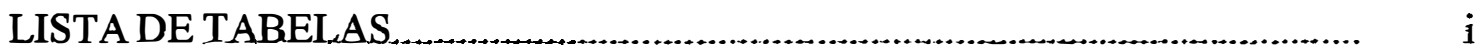

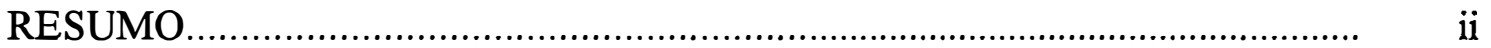

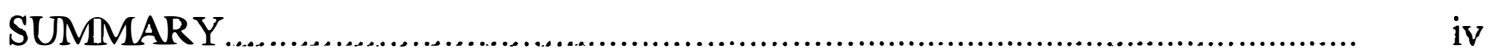

1. INTRODUÇÃO

2. REVISÃO DE LITERATURA................................................................. 3

2.1 Origem e classificação botânica das plantas cítricas................................... 3

2.1.1 Características de alguns gêneros e espécies da subfamília Aurantioideae. 7

2.2 Clorose Variegada dos Citros...................................................... 11

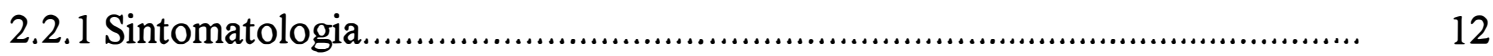

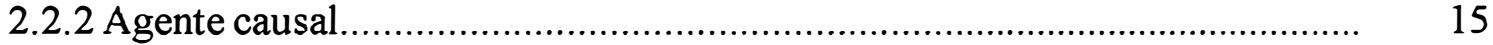

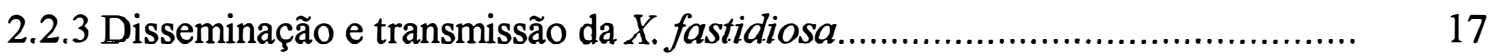

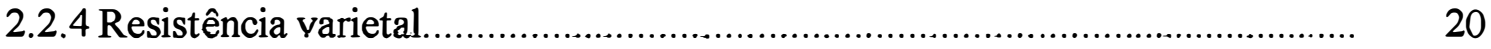

2.2.5 Teste para deteç̧ão do patógeno.......................................................... 24

3. REAÇÃO DE DIFERENTES VARIEDADES E ESPÉCIES DE CITROS A

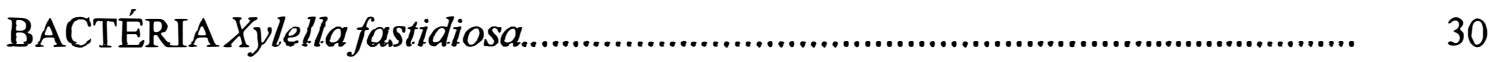

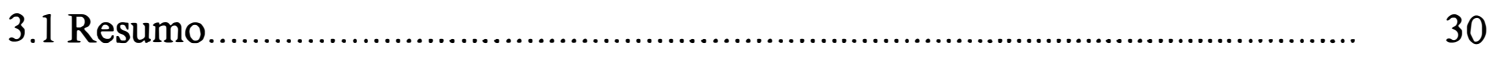

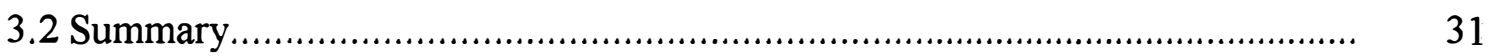

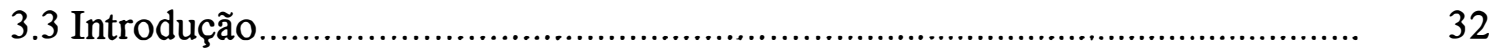

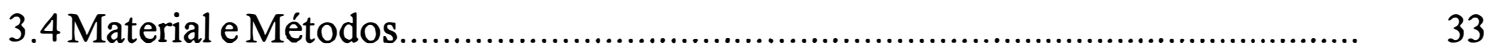

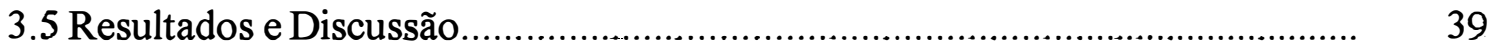

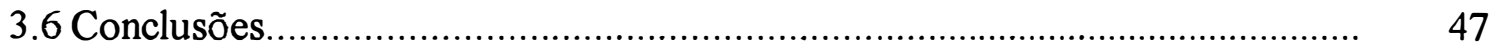

4. EFICIÊNCIA DE QUATRO MÉTODOS DE INOCULAÇÃO DE Xylella fastidiosa EM CITROS (C.itrus spp.).......................................... 49

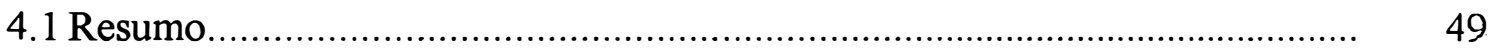

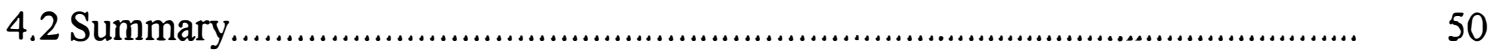

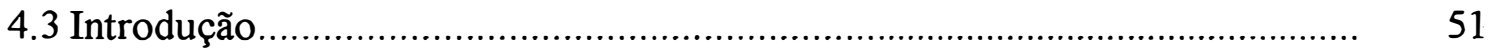

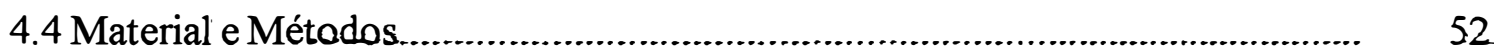


4.5 Resultados e Discussão.............................................................................. 56

4.6 Conclusões................................................................................. 60

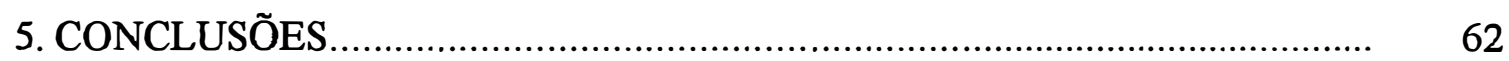

REFERÊNCIAS BIBLIOGRÁFICAS ................................................................ 64 


\section{LISTA DE TABELAS}

Páginas

1. Deteç̧ão de $X$. fastidiosa por PCR em diferentes variedades e espécies da subfamilia Aurantioideae, a partir de 2 meses após inoculação por encostia, durante um período de doze meses. Piracicaba-SP, 1999

2. Deteç̧ão de $X$. fastidiosa por PCR em diferentes variedades e espécies da subfamília Aurantioideae, a partir de 2 meses após inoculação por injeção no tronco, durante um período de seis meses. Piracicaba-SP, 1999.

3. Comparação dos resultados obtidos pelos testes PCR e ELISA para diferentes variedades e espécies da subfamília Aurantioideae. $(+)=$ positivo e $(-)=$ negativo para a presença de $X$. fastidiosa no tecido. Piracicaba-SP, 1999.

4. Concentração da bactéria $X$. fastidiosa detectada nas amostras de pecíolos das diferentes variedades experimentais através do teste ELISA, realizado a cada 45 dias, durante 4,5 meses. Piracicaba-SP, 1999.

5. Número de mudas de tangerina 'Cravo' de um total de 4 plantas por tratamento, infectadas com a bactéria X. fastidiosa em março de 1999, através de 4 métodos de inoculação e avaliadas durante 8 meses pelo teste molecular PCR. Piracicaba-SP, 1999

6. Número de mudas de três seleções de laranja 'Pera' de um total de 4 plantas por tratamento, infectadas com a bactéria $X$. fastidiosa em março de 1999, através de 4 métodos de inoculação e avaliadas durante 8 meses pelo teste molecular PCR. Piracicaba-SP, 1999 


\title{
REAÇÃo de Plantas CÍTRICAS À BACTÉRIA Xylella fastidiosa EM FUNÇÃO DE DIFERENTES MÉTODOS DE INOCULAÇÃO
}

\author{
Autora: Ariane Busch Salibe
}

Orientador: Prof. Dr. Francisco de Assis Alves Mourão Filho

\section{RESUMO}

A Clorose Variegada dos Citros é uma doença bacteriana que afeta a citricultura brasileira, reduzindo acentuadamente a produtividade da cultura. Neste trabalho, dois diferentes experimentos foram realizados com objetivo de ampliar o conhecimento sobre a doença CVC, determinando a gama de hospedeiros da Xylella fastidiosa dentro da subfamília Aurantioideae e verificando o melhor método de inoculação do patógeno em plantas cítricas. Os experimentos foram conduzidos nas instalações do Departamento de Produção Vegetal da USP/ESALQ, em Piracicaba, SP e avaliados através de testes moleculares e serológicos realizados no laboratório de Biotecnologia Molecular do Centro de Citricultura "Sylvio Moreira", Cordeirópolis, SP. Para o primeiro experimento, foram produzidas mudas de 31 representantes de espécies da subfamília Aurantioideae enxertados em limão 'Cravo' e inoculadas através de dois métodos, encostia de mudas infectadas e introdução de suspensão bacteriana no caule da muda. Os resultados do teste molecular PCR indicaram que todas as variedades de laranja 
doce testadas, como também a laranja Azeda 'São Paulo' e a cidra 'Etrog', foram hospedeiras ao patógeno da CVC e que a maior concentração da bactéria foi determinada pelo teste ELISA na variedade laranja 'Hamlin'. No segundo experimento foram avaliados quatro métodos de inoculação da $X$. fastidiosa: A. encostia de mudas infectadas, B. enxertia de pecíolos, C. garfagem lateral de ramos finos e D. inoculação com agulha de um concentrado da bactéria. As plantas testes foram as seleções de laranja 'Pera' Pirangi, GS 2000 e Ipiguá e a tangerina 'Cravo'. Avaliações mensais com o teste $\mathrm{PCR}$, realizadas durante um período de oito meses, indicaram que os métodos mais eficientes em ordem decrescente foram $B, A, C$ e D. 


\title{
REACTION OF CITRUS PLANTS TO THE BACTERIA Xylella fastidiosa RELATED TO DIFFERENT METHODS OF INOCULATION
}

\author{
Author: Ariane Busch Salibe
}

Adviser: Prof. Dr. Francisco de Assis Alves Mourão Filho

\section{SUMMARY}

Citrus variegated chlorosis is a bacterial disease presently affecting the citrus industry in Brazil, markedly decreasing the productivity of the orchards. In this research work, two different experiments were conducted with objective of enlarging the knowledge about the disease, determining the range of hosts of the pathogen Xylella fastidiosa in the sub-family Aurantioideae and finding the best method of the bacteria in the citrus plants. The experiments were conducted in the laboratories and facilities of the Department of Plant Production of the ESALQ/University of São Paulo, in Piracicaba, SP and evaluated with the use of molecular and serological tests accomplished in the Laboratory of Biotecnology of the Citrus Research Center/IAC, Cordeirópolis, SP. In the first experiment, test plant of 31 varieties and species representatives of the sub-family Aurantioideae were produced, budded on 'Rangpur' lime. They were inoculated by two methods, lateral approach grafting and introduction of bacterial suspension into the main stem of the nursery plants. The results of the PCR molecular test indicated that all varieties of sweet orange tested, as well as 'São Paulo' sour orange and the 'Etrog' 
citron were hosts of the pathogen. The highest concentration of the bacteria was determined by ELISA test to occur in the test plants of 'Hamlin' orange. In the second experiment, the efficiency of four methods of inoculation of the bacteria $X$. fastidiosa were evaluated: A. approach grafting of infected seedlings, B. petiole budding, C. grafting of young branches and $\mathrm{D}$. inoculation of bacterial suspension with needle. Tests plants were those of 'Pera' sweet orange selections Pirangi, IAC 2000 and Ipiguá and 'Cravo' mandarin. Monthly evaluations with PCR test carried on during a period of eight months revealed a marked difference between the methods of inoculation, according with the decreasing order of efficiency $B, A, C$ and $D$. 


\section{INTRODUÇÃO}

Existem basicamente três grandes regiões produtoras de citros no mundo: o Brasil, os Estados Unidos e a somatória dos países da bacia do Mediterrâneo. Dentre elas, o Brasil é o que possui a maior população mundial de plantas cítricas, estimadas em cerca de 300 milhões de árvores jovens e adultas, ocupando uma área de um milhão de hectares. É o maior produtor e exportador de suco cítrico concentrado, geranđo divisas da ordem de 1,5 bilhão de dólares anuais. Segundo Amaro (1999), oitenta por cento de todas as árvores cítricas e quase a totalidade das indústrias processadoras do Brasil estão localizadas no Estado de São Paulo.

Observa-se, contudo, uma desaceleração no plantio de novos pomares devido ao elevado custo de implantação, como também pela disseminação do Cancro Cítrico e da Clorose Variegada dos Citros (CVC) que aumentaram os riscos de perdas dos recursos investidos (Amaro, 1999).

A CVC é uma doença causada por uma bactéria limitada aos vasos do xilema, denominada Xylella fastidiosa Well que induz perdas estimadas em $30 \%$ da produção (AGRIANUAL 99). Diversas medidas preconizadas recentemente visam evitar a entrada de CVC em áreas isentas do patógeno, atenuar seus efeitos e dificultar sua disseminação no pomar.

A $X$. fastidiosa depende obrigatoriamente de insetos vetores para sua disseminação natural e penetração em tecido vegetal suscetível. Sabe-se atualmente que são onze as espécies de cigarrinhas capazes de transmitir a bactéria da CVC. Outra forma de disseminação dessa bactéria em citros é através do uso de material propagativo contaminado que torna, em curto prazo, uma muda inadequada para a produção de frutos cítricos. 
Os sintomas apresentados pela planta cítrica afetada são pouco específicos e lembram deficiência de micronutrientes como $\mathrm{Zn}$ e Mo e ainda toxidez de boro. Os frutos são pequenos, de casca lisa e muito coloridos, formam-se em penca e em grande número. As folhas das plantas com CVC mostram clorose internervais com pontuações pardas visíveis em ambos os lados do limbo foliar. Sintomas estes que podem aparecer inicialmente em um ramo ou em toda planta, levando à redução das brotações e, conseqüentemente, a um menor desenvolvimento da planta.

Esta doença parece afetar todos os cultivares comerciais de laranjeira doce no Brasil (Lee et al, 1992), sendo que até o momento, não foi observada em pomares de limão verdadeiro, lima ácida 'Tahiti', tangor 'Murcote' e tangerina 'Ponkan' (Beretta et al, 1993).

A identificação de variedades e espécies dentro do Citrus e gêneros afins, que apresentem tolerância ou resistência ao patógeno e o estudo de fatores que interferem nessa reação são fundamentais na luta contra este patógeno. As informações obtidas em estudos sobre resistência fornecem apoio aos citricultores e aos melhoristas para uma futura obtenção de variedades de laranja doce resistentes à $X$. fastidiosa. Nesse sentido, conduziu-se o presente trabalho de pesquisa objetivando-se determinar a gama de hospedeiros da $X$. fastidiosa dentro da subfamília Aurantioideae e estudar a melhor técnica de inoculação da bactéria. 


\section{REVISÃO DE LITERATURA}

\subsection{Origem e classificação botânica das plantas cítricas}

As plantas cítricas são originárias das regiões tropicais e subtropicais do continente asiático e ilhas adjacentes. Seu cultivo restringe-se a uma faixa do globo terrestre entre $40^{\circ} \mathrm{N} \mathrm{e} 40^{\circ} \mathrm{S}$ de latitude onde a temperatura mínima geralmente é superior a $-7^{\circ} \mathrm{C}$ (Davies \& Albrigo, 1994).

Segundo Tanaka (1954), são definitivamente quatro as regiões de origem dos citros. A primeira delas envolve a Indochina, a Malásia, o leste da Índia e as Ilhas do Pacífico, a segunda região seria as margens do rio Yangtze, a terceira o sul da China e a quarta e última, o Japão.

Gmitter \& Hu (1990) sugeriram que uma porção substancial do "pool" genético dos citros, representado por várias espécies indígenas, descritas por pesquisadores chineses que avaliaram o mecanismo natural de dispersão das espécies, mostra forte evidência que Yunnan e áreas próximas da China tiveram um papel crítico na origem e distribuição das novas Citrus sp.

No Brasil, as citrinas foram introduzidas pelos portugueses por volta de 1540, provavelmente na Bahia (Moreira \& Moreira, 1991), sendo que, atualmente, a maior área cultivada dos citros encontra-se situada no Estado de São Paulo.

$\mathrm{O}$ gênero Citrus pertence à subtribo Citrinae, tribo Citreae, subfamília Aurantioideae e família Rutaceae. Segundo Swingle \& Reece (1967), a subtribo Citrinae apresenta 12 gêneros que reunidos em três grupos, que são os seguintes:

- Grupo dos "citros primitivos" (Severinia, Pleiospermium, Burkillanthus, Limnocitrus 


\section{e Hesperathusa);}

- O grupo dos gêneros "próximos a citros" (Citropsis e Atalantia)

- E o grupo dos "citros verdadeiros" que inclui o gệnero Citrus e cinco outros gêneros, a saber Eremocitrus, Poncirus, Fortunella, Microcitrus e Clymenia.

Na grande maioria das espécies de Citrus, Fortunella e Poncirus, o número de cromossomos é $n=9$, sendo a diploidia $(2 n=18)$ a condição normal desses grupos de plantas (Swingle \& Reece, 1967). Exceções, todavia, podem ser verificadas como é o caso da lima ácida 'Tahiti' $(2 \mathrm{n}=3 \mathrm{x}=27)$ que se mostra poliplóide (Pompeu Júnior, 1980).

A situação taxonômica das tribos, subtribos, gêneros e espécies da subfamília Aurantioideae é bastante complexa devido à alta taxa de hibridização existente entre eles (Swingle \& Reece, 1967). A posição botânica das plantas cítricas, segundo Swingle pode ser verificada na Quadro 1.

Quadro 1. Chave dicotômica da posição botânica das espécies pertencentes à família Rutaceae.

Familia Rutaceae

\begin{tabular}{|c|c|c|c|c|c|}
\hline Subfamília & Tribos & Subtribos & Gêneros & Subgêneros & Espécies \\
\hline $\begin{array}{l}\text { Aurantioideae } \\
\text { Spatheloideae } \\
\text { Rhabdodendroideae } \\
\text { Rutoideae } \\
\text { Toddatorideae } \\
\text { Dictyolomatoideae } \\
\text { Flindersioideae }\end{array}$ & $\begin{array}{l}\text { Citreae } \\
\text { Clausenae }\end{array}$ & $\begin{array}{l}\text { Balsamocitrinae } \\
\text { Triphasiinae } \\
\text { Citrinae } \\
\\
\text { Micromelinae } \\
\text { Clauseninae } \\
\text { Merriliinae }\end{array}$ & $\begin{array}{l}\text { Hesperethusa } \\
\text { Citrus } \\
\text { Burkittanthus } \\
\text { Pleiospermium } \\
\text { Citropsis } \\
\text { Limnocitrus } \\
\text { Severina } \\
\text { Ctymenia potyandra } \\
\text { Atalantia } \\
\text { Poncirts trifoliata } \\
\text { Fortunella } \\
\text { Eremocitrus-glauca } \\
\text { Microcitrus }\end{array}$ & $\begin{array}{l}\text { Papeda } \\
\text { Eucitrus }\end{array}$ & 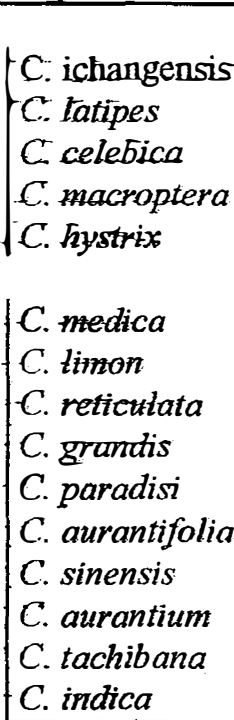 \\
\hline
\end{tabular}

(Salibe, 1969) 
A classificação das espécies de citros é muito controvertida e a literatura dá destaque a alguns estudiosos que tentaram realizá-la. Entre eles estão:

- Linnaeus (1753) que reconheceu somente duas espécies, Citrus medica L. e Citrus aurantium L (citado por Barrett \& Rhodes, 1976).;

- Swingle (1943) que relatou a existência de 16 espécies no gênero Citrus, sendo citado como excessivamente conservador;

- Tanaka (1954) que descreveu 162 espécies, mas reconhecido por alguns críticos como exagerado por ter incluído em sua classificação muitos híbridos que não garantem a condição de espécie;

- E Hodgson (1967) que, embora admitisse o sistema de Swingle, reconheceu ou aceitou a validade de um certo número de espécies descritas por Tanaka.

A tendência é aceitar o sistema intermediário de Hodgson que, embora recentes, estudos de quimiotaxonomia (Scora \& Kumamoto, 1983) e morfologia de plantas (Scora, 1988) sugerem a existência de apenas três grupos em Citrus. O primeiro "Grupo de Citrus medica L." consiste de Citrus medica L., Citrus aurantifolia L. e Citrus limon Burm. F. O segundo "Grupo de Citrus reticulata Blanco" resume-se à Citrus reticulata Blanco, Citrus sinensis L. Osbeck, Citrus paradisi Macf, Citrus aurantium L. e Citrus jambhiri Lush. E o terceiro "Grupo Citrus grandis L. Osbeck" restringe-se ao $C$. grandis $\mathrm{L}$. Osbeck. Os mesmos autores relatam a existência de uma quarta espécie denominada Citrus halimii, uma espécie ácida encontrada nas florestas das montanhas no sul da Tailândia e oeste da Malásia, mas sem importância comercial. Estes grupos derivaram de estudos utilizando dados bioquímicos, morfológicos e anatômicos e mesmo o grau de poliembrionia.

De acordo com estudos realizados por Scora \& Kumamoto (1983) e Barrett \& Rhodes (1976), as cidras (Citrus medica L.), as toranjas (C. grandis L. Osbeck) e as tangerinas (Citrus reticulata Blanco) são as únicas espécies verdadeiras de importância comercial. Provavelmente, os outros biótipos têm origem híbrida, sendo mantidos pela propagação de forma apomítica. A laranja doce parece ser um híbrido de tangerina com limão 'Rugoso' ou $C$. grandis $\mathrm{L}$. Osb., e a lima ácida um tri-híbrido 
envolvendo C. medica, C. grandis e Microcitrus (Scora, 1988). A condição de apenas três espécies ancestrais é apoiada por estudos baseados em isoenzimas, RFLP e minissatélites (Roose, 1988; Luro et al, 1992).

Malik et al. (1974) estudaram a origem do limão verdadeiro, comparandoo com cidra e lima ácida 'Galego'. As análises cromatográficas do óleo da casca e da folha de ramos com frutos maduros tornaram possivel concluir que eles devem pertencer a uma mesma espécie. Provavelmente, a cidra seria um dos progenitores, havendo contudo, uma carga genética proveniente de um grupo fora da cidra que juntamente com a lima ácida teria contribuído para sua origem.

Scora et al. (1988) realizaram uma pesquisa filogenética para verificar a posição taxonômica de $C$. halimii Stone. Análises foram feitas com extratos foliares para avaliação de isoenzimas de transaminase glutâmica oxalacética separadas em gel de amido por eletroforese. Foram incluídos no estudo treze espécies de Citrus, quatro de Fortunella, cinco de Microcitrus, uma Clausena e uma Clymenia. Os resultados indicaram que a alta freqüência de homozigose está relacionada ao isolamento genético do $C$. halimii, que mostrou homozigose em oito dos locus enzimáticos estudados. Esta tendência para homozigose indica a possibilidade de uma origem mais distante, como foi sugerido para cidra, toranja e tangerina por Handa et al. (1986).

Agarwal (1992) pesquisou a meiose de diferentes espécies de citros, como por exemplo, Citrus amblycarpa, Citrus canaliculata, Citrus depressa, Citrus hystrix, Citrus keraji, Citrus macrophylla, Citrus nakoor e Citrus shukokan. O número de cromossomos foi $2 \mathrm{n}=18 \mathrm{em}$ todas as espécies, com uma formação regular de bivalentes na meiose, indicando que os genomas de cada espécie eram homólogos e não apresentavam grandes diferenças estruturais. A presença de associações secundárias de bivalentes em C. canaliculata, C. hystrix, C. keraji, C. macrophylla e C. shukokan foi considerada indicativa de origem híbrida destas espécies.

A existência de híbridos intergenéricos é comum entre Citrus spp e gêneros afins. Davies \& Albrigo (1994) relataram um elaborado sistema de nomenclatura de híbridos desenvolvido por Swingle. Exemplos desta nomenclatura são: citranges 
[Poncirus trifoliata (L.) Raf $\times$ C. sinensis], citrandarins (P. trifoliata $x$ C. reticulata), citremons [P. trifoliata (L.) Raf $\mathbf{x}$ Citrus limon], citradias (P. trifoliata $x$ C. aurantium), citrumquats ( $P$. trifoliata $x$ Fortunella spp), eremoranges (C. sinensis $x$ Eremocitrus $\mathrm{spp}$ ), entre outros. Híbridos interespecíficos incluem os tangores (C. sinensis $x C$. reticulata), tangelos (C. paradisi $x$ C. reticulata) e lemonanges (Citrus limon $x$ Citrus sinensis).

Hodgson (1967) relata que embora a diversidade genética de Citrus seja grande, a base genética de várias espécies economicamente importantes é estreita, especialmente quando se fala de $C$. sinensis $\mathrm{L}$. Osb. (laranja doce) e $C$. paradisi Macf (pomelos). Provavelmente, a origem destas espécies se deu como híbridos interespecíficos, sendo que a proliferação de cultivares ocorreu pela seleção de mutaçoes somáticas. O autor ainda relatou que aproximadamente $24 \%$ das variedades de laranjas doce tiveram sua origem por mutações de gemas, enquanto que $23 \%$ foram obtidas a partir de mutações em "seedlings". O restante das espécies teve sua origem de forma ainda desconhecida.

\subsubsection{Características de alguns gêneros e espécies da subfamília Aurantioideae}

Diversas pesquisas foram realizadas ao longo dos anos com o intuito de se conhecer os diferentes gêneros pertencentes à subfamília Aurantioideae. Gêneros integrantes desta subfamília apresentam grande importância econômica, podendo ser para produção comercial de frutos ou para utilização de porta-enxertos que influenciem nas características das variedades copa. Alguns deles são comentados a seguir.

\section{Gênero Poncirus trifoliata (L.) Rafinesque}

Segundo Tanaka (1954), o gênero $P$. trifoliata possui apenas uma espécie monotípica que teve sua origem na China. É amplamente utilizada como porta-enxerto no Japão, na Europa e na América do Norte (Hodgson, 1967). O gênero Poncirus foi estabelecido em 1815 por Rafinesque e devido a sua tolerância ao frio, é usado hà muitos 
anos em programas de melhoramento do USDA ("United States Department of Agriculture"), visando à obtenção de porta-enxertos com características favoráveis deste gênero. Os programas de melhoramento resultaram na produção de híbridos intergenéricos, que podem ser bigenéricos como é o exemplo dos citranges (P. trifoliata $\mathrm{x} C$. sinensis) e citrumelos ( $P$. trifoliata $\mathrm{x} C$. paradisi), ou trigenéricos como citrangequats [citranges $\mathrm{x}$ Fortunella sp.] e citrangedins [citranges $\mathrm{x}$ (Fortunella $\mathrm{x}$ Citrus) 'Calamondins'] (Hodgson, 1967).

Conforme Salibe \& Roessing (1963), quando o 'Trifoliata' é utilizado como porta-enxerto para citros, apresenta as vantagens de ser altamente resistente à gomose causada por Phytophthora sp, confere precocidade à produção e excelente qualidade às frutas. A capacidade de induzir baixo vigor de crescimento da copa (porte ananicante) é uma característica do 'Trifoliata' que favorece o adensamento das plantas do pomar (Teófilo Sobrinho et al., 1984). Outra característica interessante deste gênero é a resistência ao nematóide dos citros Tylenchulus semipenetrans (Du Charme, 1948; Feder, 1968; Salibe, 1996).

Em relação à 'CVC', Li (1997) relata ser o $P$. trifoliata um hospedeiro tolerante, pois o patógeno, apesar de ser detectado na planta por testes como DIBA, ELISA e Western Blot, não causa danos ao hospedeiro, isto é , não induz sintomas conspícuos na planta infectada.

\section{Gênero Microcitnus Swingle}

É citado por Tanaka (1954) como um gênero que teve sua origem nạ Austrália. Segundo Hodgson (1967), apenas seis espécies são conhecidas, sendo que cinco delas são encontradas no oeste da Austrália que são Microcitrus australis, Microcitrus inodora, Microcitrus maideniana, Microcitrus australasica e Microcitrus garrowayi e uma apenas localizada no sudeste da Nova Guiné, a Microcitrus warburgiana. Essas seis espécies conhecidas do gênero Microcitrus são o resultado de 
milhões de anos de lenta evolução de um tipo ancestral primitivo. Deste tipo ancestral surgiu o gênero Eremocitrus (Hodgson, 1967).

O M. australasica é uma espécie que apresenta importantes características que a separam do gênero Citrus e de outras espécies que compõem o gênero Microcitrus. Seus frutos são muito longos e finos, mostrando-se com um formato único na subfamília Aurantioideae. A espécie $M$. australasica desperta 0 interesse de melhoristas para trabalhos de hibridização devido ao ótimo vigor e à produção extraordinária de ramos foliares afilados, sendo esta característica herdada pelo híbrido 'Sidney' [M. australis x M. australasica] (Hodgson, 1967).

\section{Gênero Fortunella Swingle}

Tanaka (1954) relatou que as espécies do gênero Fortunella são cosmopolitas e se diferenciam das espécies do gênero Citrus na aparência da planta em geral. As árvores de Fortunella produzem abundantes frutos de tamanho pequeno, freqüentemente menores que uma polegada de diâmetro. A espécie Fortunella margarita é denominada 'Kunquat nagami' e a Fortunella japonica é uma espécie amplamente cultivada na China e no Japão e em todas as regiões subtropicais, possuindo frutos carnudos, doces, com casca comestível, com 4 de 7 segmentos e: apresentando polpa ligeiramente ácida. Outras espécies observadas nesse gênero são a Fortunella polyandra, comumente cultivada na península Malaia e que apresenta frutos globosos com casca fina e a Fortunella hindsii que é nativa das montanhas do sul da China e em ilhas de Hong Kong, possuindo frutos globosos, muito pequenos e com três ou quatro segmentos (Hodgson, 1967).

São muitos os híbridos observados dentro do gênero Fortunella, podendo ele ser intra e intergenérico. Existem no mínimo 3 classes distintas de híbridos deste gênero, sendo (a) híbridos intragenéricos entre espécies de Fortunella (Kunquat 'Meiwa'

e 'Changshou'), (b) híbridos bigenéricos entre espécies de Fortunella e espécies de Citrus (Limequat, C. aurantifolia $\times$ Fortunella sp.), Poncirus (P. trifoliata $\times$ Fortunella 
japonica), Microcitrus ou Eremocitrus e (c) híbridos trigenéricos [(Microcitrus australasica $\times$ Fortunella sp.) x C. reticulata 'Calamondin'].

$\mathrm{Na}$ busca de plantas cítricas que forneçam material resistente a determinadas doenças fitopatogênicas, o gênero Fortunella é sempre incluído. Li (1997) estudou o Kunquat e verificou que ele se mostrava resistente à CVC devido à bactéria não ter sido detectada através de testes como ELISA, DIBA e Western Blot e por não ter sido constatado sintomas típicos da infecção $X$. fastidiosa.

\section{Gênero Citrus Linaeus.}

Tanaka (1954) relatou ser este um gênero cosmopolita que inclui dois subgêneros muito distintos, Citrus e Papeda que são facilmente distinguidos pelas características das folhas, das flores e das frutas. O subgênero Citrus que inclui todas as espécies de Citrus comumente cultivadas, possui polpa com vesículas e suco doce com um agradável nível de acidez e quase completamente livre de óleo. Ao contrário, no subgênero Papeda, nenhuma das espécies Citrus possuem frutas comestíveis, a polpa se apresenta sem vesículas, com agregações densas de óleo picante que formam uma columela axial e normalmente dão origem a suco muito desagradável, picante e de sabor amargo (Hodgson, 1967).

Dentro do subgênero Citrus, podemos encontrar diversas espécies organizadas em grupos e classificadas botanicamente (Salibe, 1969) como: A. Grupo das Laranjas que engloba duas espécies, Citrus sinensis Osbeck e Citrus aurantium Linnaeus com variedades do tipo 'Pera', 'Natal', 'Hamlin', 'Westin', 'Azeda São Paulo', 'Azeda Doble Calice', entre outros; B. Grupo das frutas ácidas onde se encontram Citrus limon Burmarn (limão 'Eureca'), Citrus aurantifolia Swingle (limão 'Galego'), Citrus limonia Osbeck (limão 'Cravo'), Citrus jambhiri Lushington (limão 'Rugoso'), Citrus medica Linnaeus (cidra), Citrus latifolia Tanaka (limão 'Tahiti'), C. Grupo das Tangerinas que inclui Citrus reticulata Blanco ('Ponkan', 'Cravo', 'Clementina'), Citrus deliciosa Tenore ('Mexerica do Rio'), Citrus unshiu Marcovitch ('Satsuma'), Citrus nobilis 
Loureiro (tangerina 'King'), Citrus reshni hort. Tanaka (tangerina 'Cleopatra'); D. Outras espécies não incluídas nestes grupos são Citrus paradisi Macfadyen (pomelos), Citrus grandis Merril (toranjas), Citrus limettioides Tanaka (lima da 'Pérsia'), Citrus limetta Risso (lima de 'Umbigo') e Citrus madurensis Loureiro ('Calamondin').

Muitas destas espécies deram origem a híbridos que freqüentemente são utilizados na citricultura comercial. $\mathrm{O}$ tangor ( $C$. sinensis $\mathrm{x} C$. reticulata) é um exemplo de híbrido que apresenta características muito parecidas com a laranja doce, produzindo frutos freqüentemente de alta qualidade (Hodgson, 1967), como é o caso da 'Murcote' e 'Temple'.

Um híbrido encontrado comumente na citricultura brasileira é o citrange (C. sinensis $\mathrm{x} P$. trifoliata), sendo que as diferentes variedades como 'Troyer' e 'Carrizo' são normalmente utilizadas como porta-enxerto, apresentando características bastante semelhantes entre eles. Ambos apresentam certa tolerância ao nematóide dos citros $T$. semipenetrans e a podridão do pé, dependendo do biotipo do nematóide e da espécie de Phytophthora (Baines et al., 1974; Klotz et al., 1967). Outro híbrido de valor é o citrumelo Swingle (C. paradisi x P. trifoliata).

Também de importância econômica é o tângelo (C. paradisi x C. reticulata) que apresenta frutos coloridos de ótimo sabor, resultante do primeiro cruzamento feito por Swingle que utilizou a técnica de polinização controlada (Hodgson, 1967).

\subsection{Clorose Variegada dos Citros}

Uma nova doença fez seu aparecimento na citricultura brasileira na década de 80, ocorrendo em pomares de laranja doce localizados nos Estados de Minas Gerais e São Paulo (De Negri, 1990; Rossetti \& De Negri, 1990; Malavolta et al., 1990 e Lee et al., 1991).

A anormalidade foi constatada pela primeira vez em laranjais do município de Colina, SP, no ano de 1987 e no município de Macaubal, SP em 1998, sendo 
conhecida inicialmente pelo nome de "Mal de Macaubal" e de "Amarelinho". Atualmente, a denominação de CVC ou Clorose Variegada dos Citros (De Negri, 1990) se deve aos sintomas foliares causados pelo patógeno responsável pela doença. Essa nomenclatura foi decidida pelo Grupo de Trabalho da CVC em 4 de janeiro de 1990 e de técnicos estrangeiros, segundo Lee et al. (1993).

A difusão desta doença acelerou nos últimos anos, de forma explosiva, contaminando pomares e viveiros de citros (Tubelis et al., 1993). Uma pesquisa realizada pelo FUNDECITRUS em 1992 revelou que 34\% da citricultura brasileira estavam infectadas pela doença e que mais de dois milhões de árvores haviam sido destruídas ou tornaram-se improdutivas pela CVC (Tubelis, 1992). A velocidade média de difusão desta doença no Estado de São Paulo foi de aproximadamente $70 \mathrm{Km} / \mathrm{ano}$ (Tubelis et al., 1993b).

Numa projeção realizada em 1993, estimou-se que a incidência da doença CVC poderia chegar a 90\%, 12 anos após a detecção da presença da primeira planta infectada, em um pomar sem nenhuma medida de controle (Gottwald et al., 1993).

Salva et al. (1995) relataram que a clorose variegada dos citros dobrou sua incidência na citricultura do Estado de São Paulo de 44\% em agosto de 1992 para $88 \%$ em maio de 1995, e afirmaram que a disseminação da doença se deu tão rápida que provavelmente todos os pomares de citros deveriam apresentar plantas hospedeiras do patógeno.

Amaro (1999) relatou que a CVC é considerada a segunda doença mais grave da citricultura paulista, sendo a primeira delas o Cancro Cítrico, doença bacteriana causada por Xanthomonas axonopodis pv. citri.

\subsubsection{Sintomatologia}

Os sintomas de CVC nas plantas cítricas afetadas pela $X$. fastidiosa se manifestam em ramos, folhas e frutos. Segundo Malavolta et al. (1990), as raízes não parecem mostrar qualquer sintoma induzido pela presença do patógeno na planta. 
Plantas cítricas sintomáticas apresentam folhas com cloroses variegadas na face superior que correspondem a pontos necróticos na face inferior da folha, oriundas do ataque de fungos secundários (De Negri,1990).

A absorção e distribuição de certos nutrientes, especialmente o zinco e o potássio, são reduzidos acentuadamente, com reflexo nos teores foliares. Essa redução aparentemente independe da concentração dos nutrientes presentes no solo ou de aplicações de micronutrientes foliares. Segundo Beretta et al. (1991), na maioria dos casos, plantas adultas afetadas pela CVC apresentam ramos com folhas miúdas. Manchas cloróticas são observadas na página ventral das folhas mais velhas, correspondendo a pequenas bolhosidades de cor palha na página dorsal, muito semelhante às manchas devido à toxicidade de boro. Análises foliares, entretanto, mostraram que não ocorre nível de boro próximo a toxicidade (Rossetti \& De Negri, 1990).

Os frutos de ramos afetados mostram-se de tamanho reduzido (1/4 - 1/3 do tamanho normal), em penca e em grande número, lembrando sintomas induzidos pela deficiência de potássio. Amarelecem prematuramente, contrastando com frutos de ramos sadios que geralmente ainda estão de cor mais verde. É comum apresentarem lesões pardas que podem atingir boa parte do fruto. Ocasionalmente, há goma pardacenta no albedo e nos gomos (Malavolta et al., 1990). Laranjeira \& Palazzo (1994) relataram que o teor de sólidos solúveis e a acidez aumentam nos frutos afetados e que isto se deve apenas ao efeito de concentração, já que o suco da fruta diminui acentuadamente. Este fato é bastante prejudicial para o comércio de frutas cítricas, já que as características desse fruto não são desejadas pelas indústrias processadoras de suco de laranja.

Malavolta \& Prates (1990) relataram a ocorrência de surtos de flores que abortam, em plantas afetadas. Segundo esses autores, análises cuidadosas do sistema radicular não revelaram qualquer anormalidade.

Sintomas de tronco, constituídos por bolsas de goma no xilema de plantas experimentais, logo abaixo da região de inoculação da bactéria foram relatados por Jacomino et al. (1993). O grau de intensidade do sintoma, considerado como uma reação 
da planta à presença do patógeno, varia em função da variedade, sendo mais intenso no tronco da tangerina 'Ponkan' e no tângelo 'Orlando'.

Machado et al. (1997) relataram que, embora haja uma correlação entre intensidade de sintomas e época do ano, estes ocorrem mais severamente nas variedades de laranja doce. Outras espécies como as tangerinas e limas ácidas podem expressar sintomas que se assemelham aos de deficiência de zinco sem, no entanto, evoluírem para sintomas típicos de CVC.

Estudos recentes realizados por Coletta Filho et al. (1997), utilizando a metodologia de deteç̧ão PCR, indicaram maior número de amostras positivas à presença da $X$. fastidiosa quando obtidas próximas aos ramos com sintomas e que alguns resultados positivos também foram verificados em amostras de ramos assintomáticos, mesmo quando provenientes de ramos mais grossos, pernadas principais e até de tronco de determinadas árvores. Os mesmos autores ainda relataram não ser possível determinar a existência de efeito da interação entre a idade da planta afetada e o grau de severidade dos sintomas observados sobre a distribuição da bactéria na planta.

Recentemente, Pria Jr et al. (2000) avaliaram os danos causados pela CVC em frutos e sementes de planta da variedade 'Valência' enxertada em tangerina 'Cleópatra' contaminada pela doença. As amostras de frutos doentes e sadios foram colhidas, pesadas e extraídas suas sementes. Estas foram analisadas quanto ao percentual de germinação e as diferenças de peso em suas partes (testa, tegma e embrião + cotilédone). Os resultados obtidos indicaram que frutos sadios apresentaram pesos muito superiores aos dos frutos doentes, 180 e $87,5 \mathrm{~g}$, respectivamente. Os resultados de "embrião + cotilédone" das sementes sadias possuíam pesos $25 \%$ superior aos das sementes doentes e mostraram um percentual de geminação após 15 dias de plantio de $85,8 \%$, sendo que somente $36,7 \%$ das sementes provenientes de frutos doentes geminaram. Os autores concluíram que a $\mathrm{CVC}$, além de causar redução no tamanho da semente, também prejudica sua germinação. 


\subsubsection{Agente causal}

A Clorose Variegada dos Citros é uma doença patogênica causada pela bactéria denominada Xylella fastidiosa Well. Segundo Well et al. (1987), essa bactéria se caracteriza por ser gram-negativa anaeróbica e se restringir aos vasos do xilema.

Garnier \& Bové (1997) relataram que as duas principais doenças cítricas que ocorrem no mundo são causadas por bactérias restritas aos tecidos vasculares: a $X$. fastidiosa que causa a CVC limitada aos tecidos do xilema e as duas estirpes de bactéria responsáveis pela doença "Greening", a Candidatus liberibacter asiaticus que ocorre na Ásia e a Candidatus liberibacter africanus que ocorre na África, limitadas ao floema.

Durante um período, diversas hipóteses a respeito da causa da CVC foram consideradas (Malavolta et al., 1990; Rossetti et al., 1997). Nos anos 1987 e 1988, pensou-se em possível causa virótica; em 1989, em desequilíbrio nutricional, com base nos sintomas apresentados pela doença (Vitti et al., 1989); em 1992, sugeriu-se que poderia haver uma causa primária a qual desencadearia a manifestação de carência de molibdênio (Costa et al., 1992); em 1992, muitos sintomas sugeriam fitotoxicidade por herbicidas, aplicados em excesso (Castro, 1992), em 1991 e 1992, Malavolta et al. (1991; 1992) afirmaram que o problema seria causado por desequilíbrio nutricional (Malavolta \& Prates, 1991; Malavolta et al., 1992).

Rossetti et al. (1990) relataram que estudos direcionados na possibilidade da CVC ser causada por bactérias limitadas aos vasos do floema como Liberobacter asiaticus e Liberobacter africanus, responsável pelo Greening, foram fundamentais na deteç̧ão de elevada população de bactérias, com morfologia similar à de X. fastidiosa, situadas nos vasos do xilema e não do floema de plantas cítricas.

Chang et al. (1993) publicaram o fechamento do postulado de Kock através da inoculação e reisolamento da bactéria $X$. fastidiosa em plantas cítricas.

Beretta (1993) também informou ter reisolado a bactéria $X$. fastidiosa na Flórida completando o postulado de Kock. Desta forma, ficou demonstrado que os 
problemas nutricionais que apareceram na sintomatologia eram conseqüência e não causa da doença CVC.

A bactéria da CVC apresenta estirpes conhecidas afetando plantas de outras espécies além dos citros, como a ameixeira, a videira, o pessegueiro, a amendoeira, a amoreira (Holpkins, 1989) e também plantas arbóreas como o olmo, o sicômoro, o carvalho e o bordo (Sherald \& Kostka, 1992).

Quadro 2. Doenças causadas pela $X$ fastidiosa, seus hospedeiros e alguns grupos da bactéria estudados.

\begin{tabular}{|c|c|c|}
\hline Doenças & Haspedeiros * & Grupos ** \\
\hline Clorose variegada dos citros ("Citrus variegated chlorosis") & Citrus sinensis L. Osbeck & citros \\
\hline Requeima do cafeeiro ("Coffee leaf scald") & Coffea arabica & - \\
\hline Mal de Pierce ("Pierce's disease") & Vitis vinifera $\mathrm{L}$. & videifa \\
\hline Requeima da folha da amoreira ("Mulberry leaf scorch") & Morus rubra $\mathrm{L}$. & amoreira \\
\hline Redução de porte do pesșegueiro ("Phony peach") & Prunus persica (L.) Batsch & - \\
\hline Escaldadura da folha da ameixcira ("Plum leaf scald") & Prunus salicina Lindl. & ameixeira-elmo \\
\hline $\begin{array}{l}\text { Escaldadura da folha da amendoeira ("Almond leaf } \\
\text { scorch") }\end{array}$ & Prunus amygdalus Batsch & amendoeira \\
\hline Requeima da folha da pereira ("Pear leaf scorch") & Pyrus pyrifolia (Bum) Nakai & - \\
\hline Nanismo da alfafa ("Alfalfa dwarf”) & Medicago sativa $\mathrm{L}$. & - \\
\hline Requeima da folha do elmo americano ("Elm leaf scorch") & Ulmus americana $\mathrm{L}$. & ameixeira-elmo \\
\hline Requeima da folha do plátano ("Sycamore leaf scorch") & Platanus occidentalis $\mathrm{L}$. & - \\
\hline Requeima da folha do carvalho ("Oak leaf scorch") & Quercus rubra L. & - \\
\hline Definhamento da vinca ("Periwinkle wilt") & Catharantus roseus (L) G. Don & - \\
\hline
\end{tabular}

Certas estirpes da $X$. fastidiosa parecem ter uma ampla gama de hospedeiros, incluindo espécie de pelo menos 28 familias de planțas monocotiledônias e dicotiledôneas (Freitag, 1951; Hopkins, 1989; Raju et al., 1980; Wells et al., 1987). Exemplo disto é a estirpe responsável pela "Doença de Pierce" que ataca a videira, sendo ainda encontrada em diversas outras plantas tanto mono como dicotiledôneas (Freitag, 
1951). Em pessegueiro, as estirpes da bactéria $X$. fastidiosa que causam "Phony Peach" também se hospedam em muitas plantas, incluindo diversos membros do gênero Prumus e outras plantas invasoras perenes como o capim maçambará (Sorghum halapense) (Wells et al., 1980). Contudo, alguns sintomas podem ser fracos ou ausentes devido à bactéria se manter em baixa concentração em alguns desses hospedeiros.

Algumas das principais espécies frutíferas, árvores e plantas ornamentais que são afetadas pela $X$. fastidiosa e as doenças associadas podem ser verificadas no Quadro 2 (Purcell \& Hopkins, 1996; Hopkins, 1989; Raju \& Wells, 1986; Rossetti et al., 1990; Lima et al., 1996; e Leu \& Su, 1993, citados por Carlos et al., 1997).

Estudos realizados por vários pesquisadores comprovam a existência de diferentes linhagens da Xylella fastidiosa, apesar desta bactéria pertencer a uma espécie bastante homogênea (Chen et al., 1992; Leite et al., 1993; Chen et al., 1995). Pooler \& Hartung (1995a), através de teste molecular RAPD, estudaram 11 linhagens de $X$. fastidiosa isoladas de diversas plantas hospedeiras e concluíram ser possível reuni-las em grupos, conforme aparece na Quadro 2.

\subsubsection{Disseminação e transmissão da $X$. fastidiosa}

Para disseminação natural da CVC e inoculação em plantas, a bactéria $X$. fastidiosa depende de insetos vetores que são cigarrinhas sugadoras de seiva do xilema de plantas. Essas cigarrinhas são vetores das diversas estirpes de $X$. fastidiosa (Gravena et al., 1997) que adquirem este patógeno durante sua alimentação. A transmissão é observada em todas as fases de desenvolvimento do inseto, principalmente quando a bactéria é adquirida na fase adulta, pois esta fase retém o patógeno pelo resto de sua vida. Em citros, 11 espécies de cigarrinhas são comprovadamente capazes de transmitir a CVC, sendo seis destas cigarrinhas identificadas recentemente por pesquisadores da FUNDECITRUS e USP/ESALQ, sendo elas: Macugonalia leucomelas, Sonesimia grossa, Ferrariana trivittata, Homalodisca ignorata, Acrogonia virescens e Parathona gratiosa. As outras cigarrinhas vetoras são: Dilobopterus costalimai, Acrogonia sp., 
Oncometopia facialis, Bucephalogonia xanthophis, Plesiommata corniculata (FUNDECITRUS, 2000).

A disseminação da "Doença de Pierce" na videira ocorre através de todas as espécies de insetos das ordens Cicadellidae e Cercopidae que se alimentam dos vasos do xilema e têm a capacidade de transmitir a bactéria da CVC demonstrada através de condições experimentais. Todavia, cigarrinhas que se alimentam do floema e que ocasionalmente provam os tecidos do xilema não são capazes de transmitir o patógeno (Golino, 1993).

Estudos realizados para várias doenças causadas pela $X$. fastidiosa têm mostrado que essa bactéria pode ser prontamente transmitida por insetos e pela propagação vegetativa (Hill \& Purcell, 1995). Holpkins (1988) relatou ter transmitido a bactéria $X$. fastidiosa pela técnica de alfinetadas. Para esta técnica, uma suspensão de bactéria foi preparada em tampão SCP (succinate-citrate-phosphate) após ser cultivada em meio de cultura PW por 4-6 dias. Usando espectrofotômetro, o autor ajustou a absorbância $(600 \mathrm{~nm})$ do inóculo (suspensão) para $0,25\left(10^{7}\right.$ a $\left.10^{8} \mathrm{cfu} / \mathrm{ml}\right)$. O processo da inoculação basicamente foi colocar uma gota da suspensão da bactéria no internódio de cada ramo jovem sadio, e em seguida, realizar uma perfuração com agulha exatamente no local onde a suspensão foi depositada até esta atingir a região do xilema. As plantas inoculadas foram mantidas em vasos dentro de casa de vegetação com uma amplitude térmica de 26 a $37^{\circ} \mathrm{C}$. O autor relata ter obtido sintomas 6 a 8 meses após a inoculação, apresentando morte dos ramos inoculados após 12-18 meses.

Fry \& Milholland (1990a) também utilizaram esta técnica de picadas por agulha para verificar translocação e multiplicação de $X$. fastidiosa em pecíolo e em ramos de videiras. A inoculação foi feita com $10 \mu$ e $20 \mu$ da suspensão da bactéria, respectivamente, através de micropipeta e com perfuração de agulha. $\mathrm{O}$ patógeno foi introduzido nos pecíolos num ponto localizado 6,5 a $7,0 \mathrm{~cm}$ da região de junção da nervura da folha com o pecíolo, e nos ramo, em dois pontos com $2,5 \mathrm{~cm}$ de distância da base do ramo. Avaliações realizadas pelo teste ELISA revelaram que a bactéria colonizou rapidamente as nervuras foliares de todos os cultivares inoculados no pecíolo, 
independentemente se estes eram tolerantes ou resistentes ao patógeno, apresentando todavia, máxima população na variedade "French Colombard" considerada suscetível. Nas plantas inoculadas, amostraram-se pedaços de ramos 2, 4 e 8 semanas após a infecção. A presença da bactéria foi verificada em videiras da variedade "French Colombard" $10 \mathrm{~cm}$ acima do ponto 2 semanas após a inoculação, mostrando a eficiência do método e a multiplicação da bactéria na planta.

Lee et al. (1991) relataram ser possível transmitir a bactéria pelo uso de borbulhas originadas de plantas doentes, sendo de grande importância a presença de lenho nas borbulhas para que ocorra a transmissão do patógeno. Machado et al. (1997) confirmaram este fato quando verificaram que plantas doentes podiam ser obtidas através da sobre-enxertia de borbulhas sadias de diferentes variedades cítricas em laranja 'Pera' com sintomas da doença. É importante relatar, todavia, que brotações de plantas hospedeiras da $X$. fastidiosa apresentam maior translocação e multiplicação do patógeno (Fry \& Milholland, 1990b).

Beretta et al. (1996) avaliaram a distribuição de $X$. fastidiosa em árvores afetadas por CVC em pomares do norte do Estado de São Paulo. Estudos sobre a distribuição da bactéria na planta foram realizados por dois anos, sendo iniciados no ano de 1993 quando as árvores tinham 3 anos de idade. Análises de extratos de tecido através dos testes "Immunobinding" e "Western blot" obtiveram resultados positivos de folhas jovens e adultas com sintomas de doença e ocasionalmente de folhas assintomáticas de ramos afetados. Em fruta madura levada de ramos sintomáticos, a bactéria foi encontrada na zona de abscisão, pedúnculo e albedo. Não havia nenhuma indicação de que a bactéria CVC estava presente em: raízes com tamanhos variados, ramos velhos, flores, sementes ou no suco do fruto.

Sugimori et al. (1995) relataram que a transmissão $X$. fastidiosa por semente não foi observada até o momento, embora algumas doenças causadas por bactérias possam ser transmitidas da planta para a semente e depois da semente para $o$ “seedling" (Khan et al., 1996).

Estudos recentes realizados com $X$. fastidiosa em cafeeiros têm mostrado 
que, apesar da bactéria ser encontrada em sementes, como por exemplo os lotes referentes aos cultivares IAPAR 59, Catuaí Vermelho, Mundo Novo, Acaiá e Sarchimor Arnarelo, não é possível constatar a presença da bactéria em mudas produzidas a partir de sementes infectadas, indicando não haver transmissão através da semente (Yorinori, 2000)

Li (1997) comparou alguns métodos de inoculação da bactéria da CVC, estudando o desenvolvimento epidemiológico da doença em laranjas doces. Os métodos de inoculação utilizados foram os seguintes: sobreenxertia de borbulhas sadias sobre plantas afetadas pela doença; garfagem de ramos finos doentes em variedades testes; inoculação em cavalos por garfagem de ramos finos; inoculação em "seedlings" por garfagem de ramos finos doentes; e ramos finos doentes sobre cavalos sadios. Os resultados obtidos pelo autor indicaram ser possível avaliar a resistência ou tolerância de variedades cítricas à $X$. fastidiosa através de borbulhas sadias sobre plantas infectadas e que este método foi o que apresentou o melhor resultado. Li (1997) ainda relata que plantas com inoculação na região do cavalo tiveram uma maior pressão de inóculo que as que tiveram a inoculação na variedade copa e por isso melhor resultado. Explicação disto seria que plantas inoculadas na região do cavalo e podadas quando inoculadas forçariam um acúmulo da bactéria na região do enxerto, ao contrário da inoculação na copa, que com ausência de uma poda, permitiu a livre translocação do patógeno e conseqüente diluição deste.

Medina et al. (1998) realizaram a transmissão da bactéria através da encostia de mudas infectadas em plantas testes. As mudas foram produzidas pela enxertia de ramos de laranjeiras da variedade 'Pera' em “seedlings" de limão 'Cravo'. Foram produzidas 80 plantas testes sadias, que aos 16 meses de idade foram transplantados para sacolas plásticas e mantidas sob telado antiinseto. A encostia de mudas contaminadas foi realizada após um mês desta ser retirada da planta adulta fornecedora do ramo infectado que deu origem à copa da muda fonte de inóculo. Depois de 5 meses da inoculação, verificou-se que as folhas da planta teste localizadas acima e ao lado da área do enxerto apresentaram sintomas, com $52,5 \%$ de traństmissão. Os autores concluíram, através dä 
detecção da bactéria pelo teste molecular PCR, que este é o mais rápido e efetivo método de infecção da $X$. fastidiosa em plantas cítricas.

\subsubsection{Resistência varietal}

Vários estudos já foram realizados na caracterização de materiais cítricos quanto à capacidade hospedeira da bactéria $X$. fastidiosa (Carvalho et al., 1995; Li et al., 1996; Machado et al., 1997) face ao caráter sistêmico do patógeno e à severidade com que a doença clorose variegada dos citros vem se manifestando nos pomares brasileiros.

As variedades de laranja doce (Citrus sinensis L. Osbeck) têm-se mostrado as mais sensíveis à CVC no Brasil, sendo a laranja 'Pera' uma das mais sensíveis segundo Lee et al. (1992) e Pompeu Jr. et al. (1994). Trabalhos realizados com variedades copa de laranja doce indicaram que, quando estas eram sobreenxertadas em laranjeiras 'Pera' sintomáticas, desenvolviam sintomas típicos da CVC, revelando resultados positivos para o agente causal pelo teste serológico DIBA (Machado et al, 1993; 1994). Conforme experimentos desenvolvidos por $\mathrm{Li}$ et al. (1996), 128 variedades ou clones de laranja doce passaram a apresentar sintomas três meses após a inoculação artificial, em condições de estufa e de campo.

Li (1997) avaliou 83 variedades e clones de laranja doce, sendo 11 variedades de laranjas precoce, 17 variedades de laranja de meia-estação, 9 variedades de laranja tardia, 23 clones de laranja 'Pêra', 13 clones de laranja 'Natal' e 10 clones de laranja 'Valência'. Os resultados indicaram que, após 3 meses da inoculação, todas as variedades e clones avaliados foram positivos pelo teste serológico DIBA e desenvolveram sintomas típicos da doença. Além disto, avaliações realizadas quanto à severidade da doença, dois anos após a inoculação, assinalaram diferenças significativas entre as variedades e clones estudados. Entre as laranjas precoces, a 'Baianinha', a 'Cadenera' e a 'Westin' foram variedades mais suscetíveis a $X$. fastidiosa, sendo que na laranja 'Baianinha' a severidade da doença é maior e na 'Westin' é menor, ficando a 'Cadenera' em posição intermediária. A 'João Nunes', 'Torregrosso' e 'Salustiana' são 
colocadas como suscetíveis, mas a severidade da doença é menor que nas outras três. Nas variedades de meia estação, as mais suscetíveis foram em ordem decrescente a 'Tarroco', 'Pera Rio', 'Ruby', 'Stratd', 'Biondo' e 'Pineapple'. Em relação às laranjas tardias, 'Valência late' revelou severidade altíssima, sendo a mais suscetível das variedades tardias testadas pelo pesquisador Li. A 'Natal 1', 'São Miguel', 'Vaccaro Blood' e 'Folha Murcha' mostraram baixa reação à infecção, não ocorrendo diferença significativa entre elas. Entre os clones de laranja avaliados, os de 'Pera' menos suscetíveis foram Fazenda Villa São João 1948, Pera 2, 'Pera' Premunizada, Nair Hernandes 1954, Vimusa, Gibran 1958 e Bianchi; de laranja 'Natal' foram Natal Murcha e Nair Sanches Filho, Nair Aidar 1954, Fazenda União 35 anos, Natal 2, Antonio Sasso 1961, Fazenda Villa São João e Natal 1; e os de Valência foram 'Valência 1', Valência 3, Valência, Werley Valência, Fazenda S. T. Jorge Ralston, Valência 2, Berry Valência, Valência PI e Sergio Pimenta 1944.

A expressão de sintomas em outras espécies de citros como as tangerinas, as limas ácidas e limões verdadeiros não são típicos, não havendo dados sobre prejuízos ou ainda conhecimento se estas espécies seriam resistentes a bactéria da CVC (Machado et al., 1993; Machado et al., 1994).

Segundo Laranjeira et al. (1995), a doença afeta as principais variedades de laranja doce sendo a laranja 'Pêra' a mais suscetível e a 'Rubi', 'Westin' e 'Ovale' as mais tolerantes. A CVC ocorre em todas as combinações porta-enxertos que são comumente usadas no Brasil, tais como: limão 'Cravo', tangerina 'Cleópatra' e limão 'Volkameriano'. Testes serológicos feitos em plantas de tangor 'Murcote' detectaram a presença da bactéria, porém os sintomas não se manifestaram. Nas demais tangerinas, não foi detectada a presença da $X$. fastidiosa. No caso do limão 'Tahiti', o teste serológico detectou a presença da bactéria, porém os sintomas do fruto não prevalecem, indicando a tolerância desta variedade ao problema (Machado et al., 1994; Li et al., 1996).

Machado et al. (1997) verificaram que entre 12 variedades de laranjas doces inoculadas com $X$. fastidiosa, e avaliadas pelo teste 'Dot Imunobiding', somente as laranjas 'Bahia' e 'Baianinha' foram negativas. As variedades dentro da espécie $C$. 
sinensis detectadas como hospedeiras da bactéria foram as laranjas 'Pera IAC', 'Pera Bianchi', 'Pera Olímpia', 'Valência', 'Folha Murcha', 'Natal', 'Hamlin', 'Barão', 'do Céu' e 'Caipira'. As tangerinas, tangores, cidra e citranges positivos quanto à presença do patógeno foram 'Parson', 'Ponkan', 'Cravo', 'Cleópatra', 'Sunki', 'Murcote', 'Etrog' e 'Troyer'.

Uma maior ou menor tolerância da variedade ao patógeno pode estar associada ao estádio de desenvolvimento do tecido da planta. Tecidos mais jovens parecem apresentar uma concentração mais baixa da bactéria. Folhas e brotações desses mesmos ramos, quando mais velhos, possuem bactéria na faixa de detecção por métodos serológicos (Machado et al., 1997). Huang et al. (1986) e Mollenhauer et al. (1976) relataram que plantas tolerantes e resistentes podem apresentar inibição da multiplicação e translocação da bactéria $X$. fastidiosa devido à presença de barreiras estruturais, substâncias inibidoras, inibidores químicos ou pelo envelhecimento da bactéria, resultando na perda de virulência.

Laranjeira et al. (1998a) avaliaram a reação de plantas dos gêneros Citrus, Fortunella e Poncirus à presença da $X$. fastidiosa sob condições de campo em cinco locais do Estado de São Paulo. Não foram feitas inoculações, sendo considerada que a transmissão ocorreu de forma natural, isto é, através de insetos vetores do patossistema. As plantas cítricas foram avaliadas visualmente, serologicamente por DIBA e "Immunoblotting" com antissoro específico para a bactéria da CVC e por PCR com “primers" específicos para o patógeno. Os resultados obtidos revelaram que todas as laranjas doces são hospedeiras sintomáticas na maioria das regiões avaliadas, demonstrando ainda a ocorrência de variações entre variedades e quando comparadas entre regiões. A única variedade fora de Citrus sinensis que apresentou sintoma da doença foi a tangerina 'Tankan', um híbrido de tangerina com laranja doce ou seja um tangor. As outras espécies e variedades avaliadas revelaram, através dos testes utilizados, ser algumas hospedeiras assintomáticas e outras não hospedeiras. As hospedeiras assintomáticas foram: as tangerinas 'Campeona', 'Clementina', 'Moreal', 'Dancy', 'Depressa', 'King' e 'Nicarágua'; os tângelos 'Lee', Mineolla', 'Orlando', 'Thornton' e 
'Weber'; tangores 'Dalmo', 'Mimosa', 'Sabará' e 'Tangerona' ; toranja 'Comprida”, limões 'Amber', 'Camargo' e 'Sanguineo 2'; e outros como Citrus natsukan, Citrus celebica, limão 'Rugoso $\mathrm{A}$ ' e 'Rugoso $\mathrm{B}$ '. As variedades não hospedeiras foram as seguintes: tangerinas 'África do Sul', 'Clementina Caçula', 'Cravo', 'Creola', 'Ellendale', 'Kara', 'Mexerica do Rio', 'Oneco', 'Ponkan', 'Satsuma' e 'Wamuco'; os tângelos 'Fairchild', 'Fremont', 'Robinson', 'Sampson', 'Sunburst', 'Osceola' e '2560'; tangores 'Fallglo', 'Murcote B.M.' e 'Murcote irradiada'; pomelos e toranjas 'Marsh Seedless', 'Star Ruby' e 'Vermelha'; limas doces e ácidas 'Dourada' e 'Tahiti'; limões 'Eureca Km 47', 'Feminello de Siracusa', 'Lisboa tetraplóide' e 'Monachello'; e outros como Poncirus trifoliata, Fortunela margarita, Citrus yuzu e o híbrido Ambersweet [ $C$. reticulata $\times$ C. paradisi) $\times$ C. sinensis].

Recentemente, observou-se em laranjais de Bebedouro, SP, que árvores enxertadas em tangerina 'Cleópatra' parecem ser menos afetadas pela CVC que aquelas em limão 'Cravo'. Também se constatou que árvores de pomelo 'Marsh Seedless', tangor 'Murcote', limão 'Eureca', tângelo 'Orlando', tangerina 'Dancy', limão 'Tahiti', limão 'Rugoso' e 21 outros citros, que não desenvolveram sintomas de CVC, dão resultado positivo para X. fastidiosa em testes de laboratório (Li, 1996; Li et al., 1996).

Laranjeira et al. (1998a) verificaram que a maioria das variedades de tângelo não apresenta sintomas de CVC, mesmo quando as plantas se encontram situadas em áreas com alta pressão de inóculo do patógeno. Testes de diagnose por PCR indicaram que diversas variedades de tângelos eram portadoras da Xylella com exceção das variedades 'Page' e 'Swanee'.

Li et al. (2000) avaliaram a suscetibilidade do limão 'Cravo' à infecção de $X$. fastidiosa. Plantas sadias de 40 cultivares de laranjeiras doces foram enxertadas sobre limoeiro 'Cravo' e levadas para o campo. Três meses após o plantio, as plantas foram inoculadas artificialmente por enxertia de ramo afetado pela CVC nas variedades de copas. Um ano depois da inoculação, as raízes de tamanho de um $\mathrm{cm}$ de diâmetro foram retiradas das plantas sintomáticas e submetidas aos testes de ELISA e PCR com "primers" específicos para Xylella. A bactéria foi detectada por ELISA e PCR, em raízes 
de 39 das 40 variedades de laranjas doces enxertadas sobre limoeiro 'Cravo' indicando que a bactéria pode descer ao limoeiro 'Cravo'.

Souza et al. (2000) avaliaram 34 variedades de laranja doce, 5 de tangerina, 3 de tângelo, 2 de citranges, um de tangor, um de pomelo, um de limão e um híbrido, sendo todas as variedades introduzidas por semente pela Estação Experimental de Citricultura de Bebedouro quanto à sua suscetibilidade a CVC. Segundo os autores do trabalho, as plantas foram inoculadas com a bactéria mediante enxertia de ramos finos doentes, empregando-se o método de garfagem lateral. A confirmação da presença da bactéria $X$. fastidiosa foi realizada através dos testes DAS-ELISA e PCR, seguida da avalią̧ão visual de sintomas da doença nas folhas. Os primeiros sintomas foram observados aos 8 meses após a inoculação, nas plantas que se mostraram hospedeiras. De acordo com os dados obtidos, os pesquisadores concluíram que dentre as variedades, os híbridos e/ou clones testados, os que se expressaram positivos ao teste PCR (as laranjas Doblefina, Seleta Tardia, Tua Graúda 1, Amares, Murtera - IVIA - 54, Setúbal,Vanilla, Convento e o Tangor Dweet IVIA-C-165) são considerados suscetíveis à X. fastidiosa.

\subsubsection{Testes para deteç̧ão do patógeno}

Diversos são os métodos utilizados para a deteç̧ão da presença da bactéria X. fastidiosa (French et al., 1977; Holpkins et al., 1988), sendo que os mais utilizados são a Reação da polimerase em cadeia (PCR) e Ensaio imunosorbente vinculado a enzimas (ELISA).

\section{Teste serológico ELISA ou "Enzyme-linked imunosorbent assay"}

O teste ELISA foi aplicado pela primeira vez na descoberta de um vírus por Avrameas (1969). Ele mostrou que, unindo covalentemente uma molécula de imunoglobina com uma enzima, era possível reter a imuno-especificidade do primeiro com as propriedades catalíticas do segundo. Aplicações com tais reagentes permitiram a 
amplificação de reações de antígeno-anticorpo com enzimas mediadoras de sensível detecção.

Desde o trabalho de Clark \& Adams (1977) onde se determinou o protocolo do teste ELISA para se verificar a presença de vírus em plantas, tem-se utilizado o teste para detecção e estimativa quantificada de um número grande de antígenos de plantas, incluindo muitos vírus patogênicos de planta, "mycoplasma-like organisms" (MLO), bactérias e fungos (Converse \& Martin, 1990).

Sherald \& Lei (1991) relataram que o teste ELISA é consistentemente efetivo na detecção de $X$. fastidiosa em extratos de folhas de plantas como o elmo, sicamore, amoras vermelhas, carvalho vermelho, mas que as plantas amostradas devem apresentar sintomas para que o teste apresente resultado positivo. $\mathbf{O}$ autor ainda cita que o teste serológico também pode ser utilizado para confirmar novos hospedeiros, examinar o movimento do patógeno na planta e verificar a existência de insetos vetores em potencial.

Segundo Lee et al. (1992), a serologia com anticorpos policlonais tem sido um dos métodos mais seguros de detecção da bactéria $X$. fastidiosa em plantas cítricas, apesar de apresentar uma resolução relativamente baixa, de no mínimo 100 bactérias por $\mathrm{ml}$.

Garnier et al. (1993) relataram que testes ELISA foram conduzidos no Brasil para deteç̧ão de $X$. fastidiosa com material fresco de plantas cítricas, obtendo-se resultados positivos com amostras de folhas sintomáticas e assintomáticas provenientes de plantas doentes sintomáticas. No caso de tecidos foliares, obtidos de árvores assintomáticas em pomares afetados ou não, todos os resultados foram negativos.

Leite et al. (1997) investigaram a presença da bactéria da CVC em plantas da vegetação rasteira de pomares de ameixeira com escaldadura da folha, para identificar possíveis hospedeiros alternativos de $X$. fastidiosa. A presença da bactéria foi verificada através do isolamento em meio de cultura BCYE e do teste DAS-ELISA utilizando um anticorpo específico produzido para a $X$. fastidiosa. Devido ao rápido crescimento de microorganismos contaminantes, o patógeno não foi constatado em meio de cultura, mas 
através do teste DAS-ELISA foi possível detectá-la em almeirão do cafezal (Hypochoeris brasiliensis), assa-peixe (Vernonia sp.), azevém (Lolium multiflorum), capim colchão (Digitaria sp.), entre outros.

\section{PCR ou "Polimerase Chain Reaction"}

Recentemente foi desenvolvido um procedimento "in vitro" com importantes aplicações na diagnose de doenças de plantas, o teste molecular PCR (Mullis et al., 1986). Esse teste possibilita a amplificação exponencial da seqüência de um DNA através de ciclos repetitivos de síntese de DNA. Cada ciclo de PCR consiste de três etapas, a desnaturação térmica $\left(92\right.$ a $\left.95^{\circ} \mathrm{C}\right)$ da fita dupla do DNA, anelamento sob temperatura redurida $\left(35\right.$ a $\left.60^{\circ} \mathrm{C}\right)$, permitindo a hibridização DNA-DNA de cada "primer" com as seqüências complementares que flanqueiam a região alvo, e por ultimo, a extensão das novas fitas de DNA, produzidas através da elevação da temperatura $\left(72^{\circ} \mathrm{C}\right)$ e com a adição de enzima DNA polimerase e de nucleotídeos (Miller \& Joaquim, 1993).

Segundo Ferreira \& Grattapaglia (1995), a tecnologia de PCR facilita estudos genéticos-moleculares envolvendo grande número de indivíduos de qualquer organismo vivo devido a sua facilidade, rapidez, versatilidade e sensibilidade.

De acordo com Henson \& French (1993), o método "Polymerase Chain Reaction" (PCR), no qual é realizada a amplificação de seqüências de DNA do patógeno, é altamente sensível na detecção da $X$. fastidiosa, sendo o mais recomendado apesar de não identificar se a bactéria está viva ou morta.

A detecção da $X$. fastidiosa tem sido realizada por PCR para os mais diversos tipos de hospedeiros, tais como citros (Beretta et al., 1997; Laranjeira et al., 1998b), videiras (Purcell \& Sauders, 1999) e cafeeiros (Lima et al., 1998) entre outros, com resultados precisos que são de grande importância para a pesquisa. 
Minsavage et al. (1994) desenvolveram um protocolo de reação da polimerase em cadeia que detecta todas as estirpes da $X$. fastidiosa com "primers" de uma região do DNA genômico que é verificado em 18 estirpes da bactéria.

Pooler \& Hartung (1995) descreveram "primers" específicos com seqüência conhecida para a estirpe da $X$. fastidiosa que causa a clorose variegada dos citros. Os "primers" específicos, CVC P2 (5' AGATGAAAACAATCATGCAAA 3') e CVC P1 (5' GCCGCTTCGGAGAGCATTCCT 3'), foram identificados através do teste molecular RAPD (Polimorfismo de DNA amplificado ao acaso) com relação genética em 11 estirpes da bactéria $X$. fastidiosa, isoladas da cultura da amora, amêndoa, erva-desantiago, uva, ameixa, elmo e citros, amplificados com 22 "primers" de 10 bases e com um total de 77 faixas polimórficas. Análises genéticas baseadas em uma matriz correspondente indicaram que os produtos obtidos da amplificação RAPD-PCR poderiam ser usados como um indicador seguro na detecção da $X$. fastidiosa.

Beretta et al. (1997) compararam diferentes estirpes da bactéria $X$. fastidiosa através do teste molecular PCR, utilizando "primers" tRNA consenso T5B e T3A e outros "primers" descritos para detecção de 18 estirpes de $X$. fastidiosa conhecidas. A estirpe da $X$. fastidiosa responsável pela doença CVC em plantas cítricas foi identificada em plantas afetadas pela doença, independentemente da presença de sintomas na plantas hospedeira.

Laranjeira et al. (1998b) determinaram se diferentes cultivares e espécies cítricas apresentavam-se hospedeiras da $X$. fastidiosa pelo teste molecular PCR. Os primers utilizados no teste de avaliação foram os mesmos descritos por Pooler \& Hartung (1995)

Purcell et al. (1999) detectaram a presença da bactéria $X$. fastidiosa em oleander através do teste molecular PCR. Os "primers" específicos utilizados no teste PCR para a bactéria foram os mesmos descritos e utilizados por Missavage et al. (1994), RST31 (5' GCGTTAATTTTCGAAGTGATTCGATTGC- 3') $^{\prime}$ e $\quad$ RST33 (5' CACCATTCGTATCCCGGTG-3'). 
Da Costa et al. (2000) isolaram e analisaram com "primers" arbitrários de DNAs genômicos através de PCR, estirpes de $X$. fastidiosa que causam a Clorose Variegada dos Citros, a Requeima da folha do Cafeeiro, a Doença de Pierce da Videira e a Requeima da Folha da Ameixeira. Produtos de 31 amplificações possibilitaram distinguir as estirpes da bactéria e construir um fenograma que mostrou as possíveis relações entre as estirpes avaliadas. As estirpes isoladas de cafeeiros doentes e de plantas cítricas com CVC foram muito semelhantes entre si, mas diferiram acentuadamente da estirpe isolada de videiras com a Doença de Pierce proveniente dos EUA. Estirpes de $X$. fastidiosa isoladas de ameixeiras doentes provenientes dos EUA e do Brasil, foram agrupadas com estirpes de diferentes hospedeiros isolados de seus respectivos paises de origem. 


\section{REAÇÃO DE DIFERENTES VARIEDADES E ESPÉCIES DE CITROS A BACTÉRIA Xylella fastidiosa}

\subsection{Resumo}

A citricultura brasileira tem sido severamente afetada pela bactéria Xylella fastidiosa, responsável pela doença Clorose Variegada dos Citros. Grandes perdas econômicas são observadas exigindo consideráveis esforços de pesquisadores para a solução do problema. Neste trabalho, 31 variedades representantes de diferentes espécies cítricas foram avaliadas quanto à sua reação à infecção pela $X$. fastidiosa. As plantas experimentais foram inoculadas por dois métodos: 1. enxertia por encostia de mudas contaminadas produzidas a partir de ramos de laranjeira 'Valência' doente e 2 . injeção no tronco da planta com suspensão bacteriana. A detecção da presença e a quantificação do patógeno foram realizadas através dos testes PCR e ELISA, respectivamente. Avaliações mensais por PCR revelaram que as plantas experimentais mantidas em contato permanente com a fonte de inóculo, resultaram em falso positivo, devido ao provável fluxo contínuo da bactéria originada do inóculo. As plantas hospedeiras da bactéria detectadas por PCR foram as laranjas doce 'Hamlin', 'Westin', 'Natal', cinco clones de laranja 'Pera' (Ipiguá, Pirangi, Bianch, IAC 2000 e IAC Premunizada), a laranja azeda 'São Paulo' e a cidra 'Etrog'. Não se detectou a presença da bactéria nas plantas experimentais inoculadas pertencentes a outras espécies de Citrus e dos gêneros Fortunella e Poncirus. Em relação à quantificação pelo teste ELISA, as reações positivas foram observadas apenas para as variedades de laranja doce, independentemente do método utilizado para a transmissão do patógeno, sendo que os 
valores foram de 1.75 a 2.57 vezes maiores que os padrões negativos. Entre plantas serologicamente positivas, a variedade 'Hamlin' mostrou a maior concentração de bactéria depois de 12 meses da inoculação, seguida da 'Pera' IAC Premunizada e da laranja 'Natal'.

\subsection{Summary: REACTION OF DIFFERENT CITRUS VARIETIES AND SPECIES TO Xylella fastidiosa}

The Brazilian citrus industry is being severely affected by Xylella fastidiosa, the causal agent of the disease named "Citrus Variegated Chlorosis". Economical losses are considerable and strong research efforts are aimed to solve the problem. In this work, 31 varieties representatives of different species of Citrus and citrus relatives were evaluated for their reaction to $X$. fastidiosa infection. Bacteria inoculation in the experimental plants was accomplished using approach grafting with young diseased buddlings and by stem injection of a bacterial suspension. PCR and ELISA tests were accomplished to detect the presence and quantification of bacteria, respectively. Monthly indexing by PCR revealed that experimental plants in permanent contact with the source of inoculum resulted in false positive, due to continuous flow of bacteria from the inoculum. Host varieties of $X$. fastidiosa were Hamlin, Westin and Natal sweet oranges, five selections of Pera sweet orange (Ipiguá, Pirangi, Bianchi, IAC 2000 and IAC Preimmunized), São Paulo sour orange, and Etrog citron. The bacterium was not detected in the infected test plants of other species of Citrus and the related Fortunella and Poncirus genera. Regarding ELISA quantification tests, positive reactions occurred only for sweet orange plants, infected by both methods with values ranging from 1.75 to 2.57 larger than negative standards. Among plants with positive values those of Hamlin showed the largest concentration of the bacteria 12 months after inoculation, followed by IAC Preimmunized 'Pera' and 'Natal' sweet oranges. 


\subsection{Introduç̃o}

As duas principais doenças dos citros que ocorrem no mundo são causadas por bactérias restritas aos tecidos vasculares. Uma delas é a Xylella fastidiosa Wells et al. (1987) limitada aos tecidos do xilema que causa a doença Clorose Variegada dos Citros (CVC) e a outra que possui duas estirpes, a Candidatus Liberobacter asiaticum que ocorre na Ásia e a Candidatus Liberobacter africanum que ocorre na África, limitadas ao floema e responsáveis pela doença "Greening" (Garnier \& Bové , 1997). Na citricultura brasileira, observa-se somente a primeira delas, todavia causando grandes perdas econômicas.

Atualmente, estima-se que o número de plantas com sintomas graves da CVC, ou seja, que apresenta um ou mais ramos com frutos pequenos, seja aproximadamente de 42 milhões de laranjeiras, havendo outros 26 milhões de plantas com sintomas em estágio inicial, classificado como nível um (árvores com sintomas apenas em folhas). Estes valores indicam um prejuízo da ordem de $\mathrm{R} \$ 235$ milhões entre perda de produção e árvores, além do custo de manejo. No total, 34,03\% do parque citrícola brasileiro, ou seja 68 milhões de árvores, têm sintomas da CVC o que confirma a estabilização da expansão da doença (FUNDECITRUS, 2000).

Sabe-se que a transmissão da bactéria ocorre principalmente de planta para planta dentro de um mesmo pomar através de cigarrinhas (Laranjeira et al., 1998a) e pelo uso de mudas contaminadas produzidas com borbulhas de plantas matrizes não certificadas (Rossetti et al., 1997). A utilização de variedades resistentes poderia ser um dos meios de controle da doença (Purcell, 1994), mas segundo Laranjeira et al. (1998b), todas as variedades de laranja doce, algumas tangerinas e híbridos são hospedeiros sintomáticos da $X$. fastidiosa. Mesmo assim, a procura de novos cultivares resistentes vem aumentando, exigindo a devida caracterização do material disponível.

Laranjeira et al. (1998b) relatam que algumas espécies cítricas tais como as tangerinas, tângelos, toranjas, cidras, limões, entre outros, hospedam o patógeno da CVC sem expressarem sintomas, sendo possível garantir a presença da bactéria apenas 
pelo emprego de técnicas de diagnose sensíveis, como serologia com anticorpos policlonais tendo resolução limite de 100 bactérias $/ \mathrm{ml}^{-1}$ (Lee et al., 1992) e PCR ("Polymerase Chain Reaction"), um teste molecular de alta precisão.

Estudos direcionados no sentido de se avaliar o comportamento de variedades cítricas já foram realizados, mas tendo em vista certa divergência com os resultados obtidos por transmissão da bactéria em condições artificiais e naturais, decidiu-se avaliar uma ampla gama de plantas cítricas, sendo estas variedades representantes de múltiplas espécies da subfamília Aurantioideae com características comercias para a citricultura brasileira. Os objetivos do presente estudo foram verificar a reação de variedades cítricas à bactéria $X$. fastidiosa através de testes moleculares e serológicos e determinar a influência do método de inoculação na resposta da planta ao patógeno.

\subsection{Material e métodos}

Seleção, obtenção e produção de mudas das variedades teste

Neste trabalho foram selecionadas 31 variedades copa da subfamilia Aurantioideae, representantes típicos das espécies as quais pertencem, para determinação e quantificação da presença de $X$. fastidiosa. As espécies e variedades selecionadas foram: a. laranjas doces (Citrus sinensis) - 'Natal', 'Hamlin', 'Westin' e 5 clones de Pera (Bianchi, Pirangi, GS 2000, Premunizada IAC e Ipiguá); b. laranjas azedas (C. aurantium) -'São Paulo' e 'Doble Cálice'; c. tangerinas (C. reticulata) 'Ponkan', 'Cravo', 'Satsuma', 'Clementina' e 'Mexerica do Rio'; d. limas doces (C. limettioides) - 'da Pérsia' e 'Dourada'; e. lima ácida (C. aurantifolia) - 'Galego'; f. lima ácida (C. latifolia) - 'Tahiti'; g. limão verdadeiro (C. limon) - 'Eureca'; h. cidra (C. medica) - 'Etrog'; i. pomelo (C. paradisi) - 'Thompson Pink' e 'Marsh Seedless'; j.toranja (C. grandis) - 'Siamesa'; k.Híbridos - tangor 'Murcote' (C. sinensis x $C$. reticulata) e tângelo 'Orlando' (C. reticulata $\mathrm{x}$ C. paradisi); 1. Citrus hytrix; m.representantes de outros gêneros - Trifoliata (Poncirus trịfoliata) - 'Trifoliata'; 
Fortunella (Fortunella margarita) - 'Kunquat Nagami', 'Kunquat Nippon' e Microcitrus sp.

As borbulhas necessárias para a formação das mudas experimentais foram obtidas do Banco Ativo de Germoplasma (BAG) do Centro de Citricultura "Sylvio Moreira"- CCSM/IAC, em Cordeirópolis, SP, sendo a sanidade dos materiais vegetativos verificada quanto à presença da $X$. fastidiosa pelo teste molecular PCR.

O limoeiro 'Cravo' (Citrus limonia) foi empregado como porta-enxerto na produção das plantas experimentais. As sementes utilizadas para a formação dos cavalos foram também provenientes do BAG do CCSM/IAC. Estas foram tratadas e semeadas conforme recomendações de Donadio (1991).

Os experimentos foram conduzidos nas dependências do Departamento de Produção Vegetal da Escola Superior de Agricultura 'Luiz de Queiroz', Universidade de São Paulo, em Piracicaba, SP, por um período de 3 anos (maio/1997 a abril/2000). Os testes moleculares e serológicos utilizados na avaliação dos experimentos foram feitos no Centro de Citricultura "Sylvio Moreira" do Instituto Agronômico, em Cordeirópolis, SP.

As plantas testes fizeram seu desenvolvimento em vasos tipo 'Citrus pot' com substrato formado de plantmax para citros (marca Eucatex), solo e areia, em uma proporção de volume de 1:1:1, permanecendo durante 2 anos sob condição de túnel plástico. Após este período, as mudas foram removidas para condição de campo.

Inoculação das plantas experimentais e delineamento estatístico.

Dois experimentos foram instalados e se diferenciaram na forma de transmissão da bactéria da CVC para as plantas testes.

No primeiro experimento, foi utilizado o método de inoculação por enxertia de material propagativo infectado com $X$. fastidiosa, sendo empregada a técnica não convencional da encostia de mudas doente proposta por Medina et al (1998). Nesta técnica, "seedlings" de limoeiro 'Cravo' com 6 meses de idade foram subenxertados em ramos de laranjeira 'Valência' doente. As mudas originadas dessa enxertia permaneceram em contato com a laranjeira doadora dos ramos por 45 dias, quando 
então, foram retiradas e trazidas para Piracicaba para serem enxertadas por encostia nas mudas experimentais. Para que a enxertia fosse realizada, foi feita uma arranhadura na casca da haste das mudas cítricas, sadias e doentes, para liberação de seiva e conseqüente favorecimento da união das mesmas. A mudas doentes serviram de fonte de inóculo por 8 meses quando finalmente foram removidas .

No segundo experimento, as plantas foram inoculadas pelo método de introdução de suspensão bacteriana no caule da planta experimental. Para este método, a bactéria $X$. fastidiosa foi cultivada em meio sólido BCYE (Wells et al, 1981) por 45 dias até a inoculação (19/02/1999) e mantida a uma temperatura de $28^{\circ} \mathrm{C}$ em BOD. No dia da inoculação, a bactéria cultivada em meio sólido foi diluída em solução tampão SCP (succinate-citrate-phosphate) e sua concentração determinada por meio de leitura ótica por espectrofotômetro. Assim, a inoculação foi realizada através da introdução de $3 \mu l$ da suspensão do patógeno por micropipeta em uma fenda produzida no caule de cada muda teste, a uma altura de $35 \mathrm{~cm}$ acima da região de união copa-cavalo, sendo a planta mantida na posição horizontal para melhor absorção da suspensão. A fenda foi protegida por fitilho plástico durante um mês para impedir a entrada de patógenos oportunistas.

A distribuição das plantas no campo para os dois experimentos obedeceu a um delineamento em blocos ao acaso com uma planta por parcela e 10 repetições para cada tratamento, sendo 5 plantas inoculadas e 5 plantas testemunhas.

Teste molecular e serológico para detecção do patógeno

A detecção da bactéria foi realizada pelo teste molecular PCR ("Polimerase Chain Reaction") e a determinação da concentração do patógeno pelo teste serológico ELISA ("Enzyme-Linked Immunosorbent Assay"). Tanto para o PCR como para o ELISA, as amostras das plantas avaliadas foram constituídas de pecíolos de folhas coletadas ao acaso na copa de cada muda. No caso do teste molecular PCR, duas folhas de cada planta/repetição foram amostradas e reunidas para formar uma única amostra com as 5 repetições de cada variedade estudada. Os testes foram feitos mensalmente, sendo que para o experimento 1 teve a duração de um ano (08/04/99 a 08/03/00) e para o experimento 2 , de seis meses (08/10/99 a 08/03/00). Para o teste 
ELISA, as avaliações foram realizadas a cada 45 dias durante quatro meses e meio, tendo 5 folhas amostradas de cada planta/repetição e a determinação da concentração realizada individualmente para cada planta (repetição).

\section{Reação da Polimerase em cadeia -PCR}

Para a extração do DNA da $X$. fastidiosa, pecíolos das folhas amostradas $(250 \mathrm{mg})$ foram triturados em nitrogênio líquido até transformação em pó. Já na forma de pó, cada uma das amostras foi distribuída em 2 tubos eppendorfs $(1,5 \mathrm{ml})$ previamente identificados. $O$ processo de extração do DNA ocorreu adicionando-se $1,8 \mathrm{ml}$ de tampão de extração CTAB-Sarcosyl (1\% do CTAB; $100 \mathrm{mM}$ de Tris-HCI pH 7,5; $10 \mathrm{mM}$ de EDTA; $0,7 \mathrm{M}$ do NaCI; $2 \%$ de Sarcosyl; $140 \mathrm{mM}$ de 2-mercaptoetanol) em cada amostra contida nos tubos. Os tubos foram incubados por 35 minutos, em banho-maria, a $60{ }^{\circ} \mathrm{C}$, sendo agitados 3 a 4 vezes nesse período e depois deixados para esfriar em temperatura ambiente. Após este esfriamento, um volume de clorofórmio (álcool isoamílico 24:1) foi adicionado aos tubos e então foram levemente agitados por 100 vezes. Após esse processo, as amostras foram centrifugadas a $12000 \mathrm{rpm}$ por 5 minutos quando se procedeu à transferência da fase superior de cada tubo para outros tubos Eppendorf. Nesta etapa, foi adicionado 0,1 volume de CTAB 10\% (10\% de CTAB; 0,7 $\mathrm{M}$ do $\mathrm{NaCI}$ ) com outro volume de clorofórmio (álcool isoamílico), seguido de 100 leves agitações e de 8 minutos de centrifugação a $12000 \mathrm{rpm}$. Transferiu-se novamente a fase superior para outros tubos eppendorfs. Foi então adicionado um volume do tampão de precipitação $\mathrm{CTAB}$, sendo este misturado cuidadosamente ao material obtido na fase superior e deixado por 15 a 30 minutos em repouso. Uma nova centrifugação foi realizada, a $10000 \mathrm{rpm}$ por 5 minutos, sendo descartados os sobrenadantes. $\mathrm{O}$ sedimento foi dissolvido em $400 \mu \mathrm{l}$ de TE alto sal (10mM de Tris-HCI pH 8,0; 1mM do EDTA 1M de $\mathrm{NaCl}$ ) em banho-maria a $60{ }^{\circ} \mathrm{C}$ até total dissolução. O DNA foi precipitado, adicionando-se dois volumes de etanol absoluto gelado e em seguida centrifugado por 10 minutos a $12000 \mathrm{rpm}$ em centrífuga refrigerada a $4{ }^{\circ} \mathrm{C}$. Removeu-se o sobrenadante e o precipitado foi lavado por duas vezes; a primeira com $700 \mu \mathrm{l}$ de etanol $70 \%$ (centrífuga por 5 minutos) e a segunda com $400 \mu$ de etanol $100 \%$ (centrifuga por 5 
minutos). Logo depois o DNA foi seco por inclinação do sobrenadante e dissolvido o "pellet" em $20 \mu \mathrm{l}$ de TE $1 / 10+$ RNAse por 1 hora a $37^{\circ} \mathrm{C}$.

A reação de amplificação do DNA foi realizada com volume de $25 \mu$, sendo 2,5 $\mu$ de tampão $10 \mathrm{X}(100 \mathrm{mM}$ de Tris-HCl pH 8,3;500mM de KCI; $25 \mathrm{mM}$ de $\mathrm{MgCl}_{2}$ e $0,01 \%$ de gelatina), $1 \mu \mathrm{l}$ de dinucleotídeos, $0,5 \mu \mathrm{l}$ de cada primer $(12,5 \mathrm{ng})$ e 0,3 $\mu \mathrm{l}$ de Taq polimerase, completando finalmente o volume com água bidestilada. Os "primers" utilizados foram os descritos por Pooler \& Hartung (1995): CVC P2 (5' AGATGAAAACAATCATGCAAA 3') e CVC P1 (5 GCCGCTTCGGAGAGCATTCCT $3^{\prime}$ ). O programa utilizado no termociclador também foi descrito por Pooler \& Hartung (1995), sendo 1 minuto a $94^{\circ} \mathrm{C}$ para desnaturação, 1 minuto a $60{ }^{\circ} \mathrm{C}$ para anelamento; 2 minutos a $72{ }^{\circ} \mathrm{C}$ para extensão, 10 minutos a $70{ }^{\circ} \mathrm{C}$ para extensão final por 30 ciclos. A visualização das reações foi feita em gel de agarose a $1 \%$, diluído em tampão TAE 50X (1 ml do tampão para $50 \mathrm{ml}$ de água destilada) e corado com brometo de etídeo $(4 \mu 1$ por $100 \mathrm{ml}$ de gel). As reações específicas para $X$. fastidiosa, causadora da CVC, foram detectadas na região de 500 pares de bases.

\section{Ensaio Imunosorbente Vinculado a Enzimas - ELISA}

O teste serológico ELISA foi realizado através da metodologia DAS (Doble Antibody Sandwich) modificada, tendo sido o antissoro específico para $X$. fastidiosa fornecido pelo Instituto Biológico de São Paulo, SP. Placas da marca Costar (96 Well Assay Plate) de fundo plano, constituídas de poliestireno de alta ligadura, foram utilizados para a realização do teste ELISA.

$\mathrm{Na}$ execução do teste, as placas foram cobertas com antissoro diluído 1:100.000 em tampão de cobertura $\left(0,159 \% \mathrm{NaCO}_{3}, 0,293 \% \mathrm{NaHCO}_{3}, 0,02 \% \mathrm{KH}_{2} \mathrm{PO}_{4}\right.$, $0,29 \% \mathrm{Na}_{2} \mathrm{HPO}_{4} \cdot 12 \mathrm{H}_{2}, 0,02 \% \mathrm{KCl}, \mathrm{pH} 7,2$ - 7,4) e incubadas durante 60 minutos a 37 ${ }^{0} \mathrm{C}$. Após esta fase, adicionaram-se as amostras (antígenos), distribuindo-as ao acaso pelas placas e incubando-as por 60 minutos e $37^{\circ} \mathrm{C}$. Cada placa recebeu um total de 45 amostras de plantas testes, e ainda, uma amostra de controle negativo obtida de muda certificada conduzida em cultivo protegido, uma amostra de controle positivo 
proveniente de planta infectada com sintomas da CVC e outra amostra positiva formada de suspensão bacteriana produzida em meio de cultura sólido BCYE. Todas as amostras tiveram duas repetições na placa de ELISA.

Em seguida à adição do antígeno, foi adicionado o anticorpo diluído 1:100.000 em tampão PBS e então incubado por mais $60 \mathrm{~min}$, a $37{ }^{\circ} \mathrm{C}$. Adicionou-se então, o conjugado anti-rabbit IgG fosfatase alcalina (Sigma) diluído 1:7.000 em tampão PBS, incubando a placa durante 60 minutos a $37^{\circ} \mathrm{C}$. O substrato, P-nitrofenol fosfato (PNPP, Sigma) diluído em tampão de dietanolamina $(1 \mathrm{mg} / \mathrm{ml})$ foi adicionado e também incubado à temperatura ambiente durante 30-60 minutos. Após o desenvolvimento de coloração amarela, foi medida a absorbância a $405 \mathrm{~nm}$ em leitor de placas de ELISA. Entre cada passo, a placa foi lavada três vezes com PBS-Tween (0,5 ml Tween 20/litro).

Os valores de absorbância obtidos pelo leitor de ELISA para cada amostra foram registrados e a média dos valores das repetições/amostras da placa, calculada. Para considerar um determinado valor de absorbância como positivo ou negativo, utilizou-se o seguinte procedimento, indicado por Zar (1996): inicialmente a distribuição dos valores dos controles negativos de todas as placas submetidas ao ELISA passou pelo teste de distribuição normal (software STATISTICA, Statsoft, Tulsa, AZ). Confirmada essa distribuição, optou-se pela admissão de um erro de $0,1 \%$. Para um erro de $0,1 \%$, o valor da absorbância máxima para amostras negativas foi de 0,143 ; já que a média das amostras negativas foi de 0,056 e o desvio padrão, $0,028\{0,143=0,056+$ $(3,09 \times 0.028)\}$. Considerou-se como positiva qualquer amostra com valor superior à média das amostras negativas somada ao produto entre 3,09 e o valor do desvio padrão das amostras negativas.

Para se determinar a diferença de concentração da bactéria entre as amostras positivas e quantas vezes sua concentração era maior que os valores da amostra sadia (controle negativo), foram divididos os valores de absorbância das amostras positivas pelo valor do controle negativo da placa correspondente.

Foi verificado também, o grau de detecção e de determinação da bactéria pelo teste serológico ELISA através da diluição em série da suspensão de $X$. fastidiosa, seguida de plaqueamento com contagem do número de unidades de colônias formadoras 
por ml em cada diluição, comparado-o com o resultado da absorbância obtido no teste ELISA também para cada diluição.

\subsection{Resultados e Discussão}

\section{Detecção da bactéria por PCR}

Os resultados do primeiro experimento obtidos por reações específicas para $X$. fastidiosa através de PCR, dois meses após a inoculação por enxertia, podem ser observados na Tabela 1. Verificou-se que durante o período em que a fonte de inóculo permaneceu em contato com as plantas experimentais, a maioria das variedades e espécies da subfamília Aurantioideae foi hospedeira da bactéria da CVC. Exceções foram observadas apenas para variedades de laranja doce como 'Hamlin', 'Natal', 'Westin', algumas seleções 'Pera' (Bianchi, IAC.2000 e Ipiguá), tangerina 'Ponkan', 'Satsuma', Mexerica do Rio', tangor 'Murcote', tângelo 'Orlando', toranja 'Siamesa', 'Trifoliata' e Citrus histrix D.C.

A detecção da $X$. fastidiosa nas variedades de 'Pera' Pirangi e 'Pera' Premunizada IAC durante toda a avaliação está de acordo com relatos de Laranjeira et al. (1995), Laranjeira et al. (1998b), Malavolta et al. (1993), Machado et al. (1993), mas a ausência da deteç̧ão do patógeno nas outras variedades de laranja doce estudadas durante os 6 primeiros meses de análises por PCR contradiz os dados já publicados por Li (1997) e Laranjeira et al. (1998a,b). Todas as limas ácidas e doces, limões e pomelos amostrados e avaliados por PCR mostraram-se portadores não sintomáticos da bactéria, não corroborando com os trabalhos realizados por Machado et al. (1997), concordando com relatos de Beretta et al. (1993) para a lima ácida 'Tahiti'.

Observaram-se nas avaliações algumas alternâncias entre resultados positivos e negativos para certas variedades na detecção da $X$. fastidiosa, sugerindo que a amostragem feita em ramos escolhidos ao acaso na planta em condição de campo e a distribuição irregular do patógeno na planta interferem nos resultados . 
Tabela 1. Detecção de $X$. fastidiosa por PCR em diferentes variedades e espécies da subfamilia Aurantioideae, a partir de 2 meses após inoculação por encostia, durante um período de doze meses. Piracicaba-SP, 1999.

\begin{tabular}{|c|c|c|c|c|c|c|c|c|c|c|c|c|c|}
\hline \multirow{2}{*}{ Espectes } & \multirow{2}{*}{ Variedades } & \multicolumn{6}{|c|}{ Avaliacoóes -PCR } & \multicolumn{4}{|c|}{$(08 / 04 / 99$ a $08 / 03 / 00)$} & \multirow[b]{2}{*}{$11^{2}$} & \multirow[b]{2}{*}{$12^{2}$} \\
\hline & & $1^{4}$ & 2 & 3 & 4 & 5 & 69 & 7 & 8 & $9^{p}$ & $10^{2}$ & & \\
\hline \multirow[t]{8}{*}{ Laranjas doces } & 'Hamlin' & - & - & - & $=$ & + & + & + & + & + & + & + & + \\
\hline & 'Natal' & - & - & - & - & - & - & - & + & + & + & + & + \\
\hline & 'Westin' & - & - & - & - & - & - & - & - & + & + & + & + \\
\hline & 'Pera' Bianchi & - & - & - & - & - & - & - & - & - & + & + & + \\
\hline & 'Pera' IAC .2000 & - & - & - & - & - & - & + & + & + & + & + & + \\
\hline & 'Pera' Ipiguá & - & - & - & - & - & - & + & + & + & + & + & + \\
\hline & 'Pera' Pirangi & + & - & + & + & + & + & + & + & + & + & + & + \\
\hline & 'Pera' Premunizada IAC & - & - & + & + & + & + & + & + & + & + & + & + \\
\hline \multirow[t]{5}{*}{ Tangerinas } & 'Cravo' & + & - & + & + & + & + & + & + & - & - & - & - \\
\hline & 'Ponkan' & - & - & - & - & - & - & - & - & - & - & - & - \\
\hline & 'Clementina' & - & - & - & + & + & + & + & + & - & - & - & - \\
\hline & 'Satsuma' & - & - & - & - & - & - & - & - & - & - & - & - \\
\hline & 'Mexerica do Rio' & - & - & - & - & - & - & - & - & - & - & - & - \\
\hline Tangor & 'Murcote' & - & + & - & - & - & - & - & - & - & - & - & - \\
\hline \multirow[t]{2}{*}{ Limas ácidas } & 'Galego' & + & - & + & + & + & + & + & + & - & - & - & - \\
\hline & 'Tahiti' & - & - & + & + & + & + & + & + & - & - & - & - \\
\hline Limão verdadeiro & 'Eureca' & - & - & + & + & + & + & + & + & + & - & - & - \\
\hline \multirow[t]{2}{*}{ Limas doces } & 'Dourada' & - & - & + & + & + & + & + & + & - & - & - & - \\
\hline & 'Pérsia' & - & - & + & + & + & + & + & + & - & - & - & - \\
\hline \multirow[t]{2}{*}{ Pomelo } & 'Marsh Seedless' & - & - & + & + & + & + & + & + & - & - & - & - \\
\hline & 'Thompson Pink' & - & - & + & + & + & + & + & + & - & - & - & - \\
\hline Tângelo & 'Orlando' & - & - & - & - & $=$ & - & - & - & - & - & - & - \\
\hline \multirow[t]{2}{*}{ Laranjas azedas } & 'São Paulo' & - & + & + & + & + & + & + & + & + & - & + & + \\
\hline & 'Doble Calice' & - & - & + & + & + & + & + & + & - & - & - & - \\
\hline Toranja & 'Siamesa' & - & - & - & - & - & - & - & - & - & - & - & - \\
\hline Cidra & 'Etrog' & - & - & + & + & + & + & + & + & + & + & + & + \\
\hline Citrus histrix D.C. & & $=$ & - & - & - & - & - & - & - & - & - & - & - \\
\hline \multirow[t]{2}{*}{ Fortunella } & Kunquat Nagami. & + & - & + & + & + & + & + & + & - & - & - & - \\
\hline & Kunquat Nippon & - & - & + & + & + & + & + & + & - & - & - & - \\
\hline Microcitrus sp. & & - & - & + & + & + & + & + & + & + & - & - & - \\
\hline Poncirus trifoliata & Trifoliata & - & - & $=$ & - & - & - & - & - & - & - & - & - \\
\hline
\end{tabular}

Alteração consistente passou a ocorrer para muitas variedades estudadas, oito meses após a inoculação, quando a muda fonte do patógeno foi retirada das plantas testes. Provavelmente, esta prática forneceu a internupção do fluxo de seiva infectada proporcionado pelas mudas portadoras do patógeno, impedindo assim, o livre trânsito da bactéria na planta. Diversas variedades representantes de diferentes espécies cítricas, que 
foram identificadas pelo teste PCR como hospedeiras do patógeno da CVC durante os 6 primeiros meses de avaliação (Tabela 1), passaram a ser classificadas como resistentes, podendo-se concluir que o patógeno, apesar de transitar pela planta, não se estabeleceu e nem se multiplicou no hospedeiro. Quando a fonte de inóculo foi retirada, a planta experimental necessitou aproximadamente 2 meses para mostrar-se não hospedeira da bactéria da CVC. Segundo relatos de Huang et al. (1986) e Mollenhauer et al. (1976), plantas tolerantes e resistentes podem apresentar inibição da multiplicação e translocação da bactéria $X$. fastidiosa devido à presença de barreiras estruturais, substâncias inibidoras ou pelo envelhecimento da bactéria, resultando na perda de sua patogenicidade.

Conforme resultados obtidos após um ano de avaliação por PCR, todas as variedades de laranja doce, selecionadas e avaliadas neste experimento, foram hospedeiras da X. fastidiosa, concordando com os relatos de Lee et al. (1992) e Pompeu Jr. et al. (1994) onde afirmam que algumas variedades de laranja doce são muito sensíveis à CVC no Brasil.

Os resultados das análises mostram a presença da bactéria nas variedades de laranja azeda 'São Paulo' e de cidra 'Etrog'. Segundo avaliações realizadas por Laranjeira et al. (1998b), a variedade cidra 'Etrog', mesmo não apresentando sintomas de CVC, mostra-se portadora da bactéria. Relatos sobre laranja azeda 'São Paulo' não foram feitos pelos autores.

No segundo experimento, a inoculação da bactéria $X$. fastidiosa através de suspensão bacteriana foi realizada nas 31 variedades cítricas em outubro de 1999. Antes da inoculação, a concentração da suspensão da bactéria foi determinada por espectrofotômetro, revelando uma absorbância $(600 \mathrm{~nm})$ correspondente a $1,98 \times 10^{7}$ $\mathrm{ufc} / \mathrm{ml}$.

A resposta ao método de inoculação por suspensão foi rápida, podendo-se detectar a presença do patógeno pelo teste PCR seis meses após a infecção em quase todas as variedades e seleções de laranja doce ensaiadas. Apenas a laranja doce 'Westin' não se mostrou hospedeira da bactéria da CVC neste período. Este resultado está de acordo com relatos de Laranjeira et al. (1995) que verificou que a doença afeta 
principalmente as variedades de laranja doce e que a 'Rubi', 'Westin' e 'Ovale' mostram-se hospedeiros tolerantes ao patógeno.

Tabela 2. Detecção de $X$. fastidiosa por PCR em diferentes variedades e espécies da subfamília Aurantioideae, a partir de 2 meses após inoculação por injeção no tronco, durante um período de seis meses. Piracicaba-SP, 1999.

\begin{tabular}{|c|c|c|c|c|c|c|c|}
\hline \multirow{2}{*}{ Especies } & \multirow{2}{*}{ Variedades } & \multicolumn{3}{|c|}{ Avaliacoes $-\mathbf{P C R}$} & \multicolumn{3}{|c|}{$(08 / 10 / 99$ a $08 / 03 / 00)$} \\
\hline & & $1^{\mathrm{n}}$ & $2^{8}$ & $3:$ & 4 & $5^{2}$ & $6^{2}$ \\
\hline \multirow[t]{8}{*}{ Laranjas doces } & 'Hamlin' & - & - & - & + & + & + \\
\hline & 'Natal' & - & - & - & - & + & + \\
\hline & 'Westin' & - & - & - & - & - & - \\
\hline & 'Pera' Bianchi & - & - & - & - & - & + \\
\hline & 'Рета' IAC.2000 & - & - & - & - & + & + \\
\hline & ‘Pera’ Ipiguá & - & - & - & - & - & + \\
\hline & 'Pera' Pirangi & - & - & - & - & $\div$ & + \\
\hline & 'Pera' Premunizada IAC & - & - & - & - & - & + \\
\hline \multirow[t]{5}{*}{ Tangerinas } & 'Cravo' & - & $\bar{n}$ & - & - & - & - \\
\hline & 'Ponkan' & - & - & - & - & - & - \\
\hline & 'Clementina' & - & - & - & - & - & - \\
\hline & 'Satsuma' & - & - & - & - & - & - \\
\hline & 'Mexerica do Rio' & - & - & - & - & - & - \\
\hline Tangor & 'Murcote' & - & - & - & - & - & - \\
\hline \multirow[t]{2}{*}{ Limas ácidas } & 'Galego' & - & - & - & - & - & - \\
\hline & 'Tahiti' & - & - & - & - & - & - \\
\hline Limão verdadeiro & 'Eureca & - & - & - & - & - & - \\
\hline \multirow[t]{2}{*}{ Limas doces } & 'Dourada' & - & - & - & - & - & - \\
\hline & 'Pérsia' & - & - & - & - & - & - \\
\hline \multirow[t]{2}{*}{ Pomelo } & 'Marsh Seedless' & - & - & - & - & - & - \\
\hline & 'Thompson Pink' & - & - & - & - & - & - \\
\hline Tângelo & 'Orlando' & - & - & - & - & - & $t$ \\
\hline \multirow[t]{2}{*}{ Laranjas azedas } & 'São Paulo' & - & - & - & - & - & - \\
\hline & 'Doble Calice' & - & - & - & - & - & - \\
\hline Toranja & 'Siamesa' & - & - & - & - & - & - \\
\hline Cidra & 'Etrog' & - & - & - & - & - & - \\
\hline Citrus histrix D.C. & & - & - & - & - & - & - \\
\hline \multirow[t]{2}{*}{ Fortunella } & 'Kunquat Nagami' & - & - & - & - & - & - \\
\hline & 'Kunquat Nippon' & - & - & - & - & - & - \\
\hline Microcitrus sp. & & - & - & - & - & - & $=$ \\
\hline Poncirus trifoliata & 'Trifoliata' & - & - & - & - & - & - \\
\hline
\end{tabular}


Segundo as reações de PCR, observadas em gel de agarose, pode-se verificar que, além das variedades de laranja doce, a variedade tângelo 'Orlando' foi hospedeira da bactéria, confirmando o resultado obtido por $\mathrm{Li}$ (1996), Li et al. (1996) e Laranjeira et al. (1998a,b). Os resultados positivos obtidos na reação de amplificação do DNA para a presença da $X$. fastidiosa podem ser verificados na Tabela 2 .

Além da laranja 'Westin', não foi verificada a presença da bactéria nas plantas das variedades cidra 'Etrog' e laranja azeda 'São Paulo' que foram inoculadas pelo método de introdução de suspensão bacteriana no tronco da planta. Estes resultados discordam dos dados obtidos no experimento um, pois variedades que não se mostram hospedeiras da bactéria foram detectadas portadoras do patógeno por PCR quando o método de inoculação foi o de enxertia, confirmando resultados obtidos no item 4 , no qual se constatou diferença na eficiência de transmissão da $X$. fastidiosa entre diferentes métodos de inoculação.

De acordo com os dados obtidos no teste molecular PCR para ambos os experimentos, não foi detectada a presença da bactéria da CVC nos tecidos das variedades de tangerina, tangor, limas ácidas, limão verdadeiro, limas doces, pomelos, toranjas, Citrus histrix D.C., Fortunella, Microcitrus sp. e Poncirus trifoliata. Resultados como estes confirmam relatos de $\mathrm{Li}$ (1997) e Laranjeira et al. (1998b).

Determinação da concentração da X. fastidiosa nas variedades de citros por ELISA.

A comparação dos resultados obtidos no teste serológico ELISA e no teste molecular PCR para as diferentes variedades e espécies de citros estudadas quanto à capacidade hospedeira a $X$. fastidiosa estão expressos na Tabela 3 .

$O$ teste ELISA revelou que a bactéria se encontra presente em diferentes concentrações nas variedades e seleções de laranja doce, confirmando relatos de Carvalho et al. (1995), Laranjeira et al. (1995), Li et al. (1996) e Laranjeira et al. (1998b) que demonstraram a diferença de reação entre cultivares de laranja doce, independentemente do método de inoculação, natural ou induzido. 
Tabela 3. Comparação dos resultados obtidos pelos testes PCR e ELISA para diferentes variedades e espécies da subfamília Aurantioideae. $(+)=$ positivo e $(-)=$ negativo para a presença de $X$. fastidiosa no tecido. Piracicaba-SP, 1999.

\begin{tabular}{|c|c|c|c|c|}
\hline \multirow[t]{2}{*}{ Espécies/ variedades } & \multicolumn{2}{|c|}{$\begin{array}{c}\text { Experimento } 1 \\
\text { (Enxertia por encostia) }^{c} \\
(08 / 03 / 00)\end{array}$} & \multicolumn{2}{|c|}{$\begin{array}{c}\text { Expenmento 2 } \\
\text { (Suspensão bacteriana) }^{c} \\
(08 / 03 / 00)\end{array}$} \\
\hline & $\mathrm{PCR}^{\mathrm{a}}$ & FIISA & $\mathrm{PCR}^{\mathrm{a}}$ & FIISA \\
\hline 'Hamlin' & + & + & + & + \\
\hline ‘Natal' & + & + & + & + \\
\hline 'Westin' & + & + & - & - \\
\hline 'Pera' Bianchi & + & + & + & + \\
\hline 'Pera' IAC.2000 & + & + & + & + \\
\hline 'Pera' Ipiguá & + & + & + & + \\
\hline 'Pera' Pirangi & + & + & + & + \\
\hline 'Pera' Premunizada IAC & + & + & + & + \\
\hline 'Cravo’ & - & - & - & - \\
\hline 'Ponkan' & - & - & - & - \\
\hline 'Clementina' & - & - & - & - \\
\hline 'Satsuma' & - & - & - & - \\
\hline 'Mexerica do Rio' & - & - & - & - \\
\hline 'Murcote' & - & - & - & - \\
\hline 'Galego' & - & - & - & - \\
\hline 'Tahiti' & - & - & - & - \\
\hline 'Eureca & - & - & - & - \\
\hline 'Dourada' & - & - & - & - \\
\hline 'Pérsia' & - & - & - & - \\
\hline 'Marsh Seedless' & - & - & - & - \\
\hline 'Thompson Pink' & - & - & - & - \\
\hline 'Orlando' & - & - & + & - \\
\hline ‘São Paulo’ & + & - & - & - \\
\hline 'Doble Calice' & - & - & - & - \\
\hline 'Siamesa' & - & - & - & - \\
\hline 'Etrog' & + & - & - & - \\
\hline Citrus histrix D.C. & - & - & - & - \\
\hline Kunquat Nagami. & - & - & - & - \\
\hline Kunquat Nippon & - & - & - & - \\
\hline Microcitrus sp. & - & - & - & - \\
\hline Trifoliata & - & - & - & _- \\
\hline
\end{tabular}


Verificou-se, porém, nos dados obtidos que o teste ELISA não foi suficientemente sensível para determinar o nível de concentração do patógeno em variedades como laranja azeda 'São Paulo', cidra 'Etrog' e tângelo 'Orlando', verificadas como hospedeiras da bactéria pelo teste molecular PCR. Para o tângelo 'Orlando', essa mesma situação já havia sido detectada por Laranjeira et al. (1998a), que também relataram a laranja azeda e a cidra como espécies hospedeiras de $X$. fastidiosa (Laranjeira et al., 1998b). Segundo Machado et. al. (1997), uma maior ou menor concentração da bactéria inferida por testes serológicos pode estar associada ao estádio de desenvolvimento do tecido da planta. Tecidos jovens apresentariam menor concentração da bactéria que tecidos mais velhos. Contudo, deve-se ressaltar que as mudas formadas com as diversas variedades testes apresentavam a mesma idade e as folhas amostradas eram provenientes do mesmo ciclo vegetativo da planta, concluindose que uma maior dificuldade foi encontrada pela bactéria para se estabelecer nas plantas identificadas como hospedeiras da X fastidiosa por PCR e não detectadas por ELISA.

O método de desvio padrão de uma distribuição normal (Zar, 1996) adequou-se para determinação das amostras positivas, não sendo encontrados resultados em discordância com aqueles obtidos com o teste PCR (Tabela 1 e 2). Face ao grande número de placas necessárias para a avaliação das variedades experimentais, foi necessário padronizar os resultados para uma comparação das concentrações da bactéria entre variedades. Dividiu-se então, o valor das amostras positivas pelo controle negativo médio de cada placa, estando os resultados apresentados na Tabela 4.

Os valores obtidos com a padronização das concentrações revelaram que as amostras da variedade de laranja 'Hamlin' se apresentaram 2,57 vezes mais elevados que os. padrões negativos. Entre plantas serologicamente positivas, a variedade 'Hamlin' mostrou a maior concentração de bactéria depois de 12 meses da inoculação, seguida da 'Pera' IAC Premunizada e da laranja doce 'Natal'.

As menores concentrações verificadas entre as variedades, detectadas como portadoras da bactéria pelo teste ELISA na ultima avaliação, foram a laranja 'Pera' IAC 2000 no experimento 1 e a laranja 'Westin' para o experimento dois, que 
apresentaram valores 1,75 e 1,50 vezes mais elevados que os padrões negativos, respectivamente.

Tabela 4. Concentração da bactéria $X$. fastidiosa detectada nas amostras de pecíolos das diferentes variedades experimentais através do teste ELISA, realizado a cada 45 dias, durante 4,5 meses. Piracicaba-SP, 1999.

\begin{tabular}{|c|c|c|c|c|c|c|}
\hline \multirow[t]{3}{*}{ Hospedeiros } & \multicolumn{6}{|c|}{ TESTE ELISA (A) } \\
\hline & \multicolumn{3}{|c|}{${\text { Experimento } 1^{\mathrm{b}}}^{-1}$} & \multicolumn{3}{|c|}{ Experimento $2^{\mathbf{c}}$} \\
\hline & $1^{a}$ & $2^{\mathrm{a}}$ & $3^{\mathrm{a}}$ & $1^{a}$ & $2^{\mathrm{a}}$ & $3^{a}$ \\
\hline 'Hamlin' & 1,40 & 1,68 & 2,57 & 1,46 & - & 2,57 \\
\hline 'Natal' & 1,54 & 1,89 & 2,20 & - & 1,71 & 2,04 \\
\hline 'Westin' & - & - & 1,76 & - & - & 1,50 \\
\hline 'Pera' Bianchi & 1,38 & 1,48 & 2,45 & 1,39 & 1,41 & 1,61 \\
\hline 'Pera' IAC.2000 & - & - & 1,75 & - & 1,65 & 2,08 \\
\hline ‘Pera' Ipiguá & - & 2,28 & 2,12 & - & 1,77 & 2,04 \\
\hline 'Pera' Pirangi & 1,45 & - & 2,29 & - & 1,68 & 1,99 \\
\hline 'Pera' Premunizada IAC & 1,22 & 1,55 & 2,52 & 1,72 & 1,70 & 2,00 \\
\hline Controle positivo médio & 2,73 & 2,64 & 2,55 & 2,73 & 2,64 & 2,55 \\
\hline Controle negativo médio & 0,052 & 0,099 & 0.092 & 0,052 & 0,099 & 0,092 \\
\hline
\end{tabular}

${ }^{\mathrm{a}}(\mathrm{A})$ = Valor de absorbância ou concentração da bactéria determinada pelo leitor de FII ISA.

b Plantas inoculadas por enxertia com método de encostia de mudas doentes.

${ }^{c}$ Plantas inoculadas por suspensão bacteriana na haste da planta teste.

O teste ELISA é considerado uma forma confiável de medir a concentração da bactéria nos tecidos das plantas portadoras de $X$. fastidiosa. A intensidade da reação de uma amostra, quando positiva, determina a presença e a concentração do patógeno. Segundo Minsavage et al. (1994), o patógeno de plantas hospedeiras assintomáticas são detectáveis por ELISA quando se encontram no sistema vascular da planta com uma concentração mínima de $1.3 \times 10^{5} \mathrm{ufc} / \mathrm{ml}$ e por PCR com $1.3 \times 10^{3} \mathrm{ufc} / \mathrm{ml}$, mostrando que o teste PCR é 100 vezes mais sensível que o ELISA.

Determinação da sensibilidade do teste ELISA

A diluição em série de uma suspensão da bactéria $X$. fastidiosa foi realizada com o intuito de determinar a sensibilidade do teste ELLISA na detecção do patógeno. Observou-se que o limite médio para detecção da bactéria pelo teste ELISA 
foi o valor da diluição da suspensão de $X$. fastidiosa com resultado 1,4 vez maior que a média do controle negativo na placa de ELISA. Esse resultado corresponde a 1,5 x $10^{4}$ $\mathrm{ufc} / \mathrm{ml}$ determinado pelo plaqueamento da diluição em meio de cultura PCYE e contagem das unidades formadoras de colônias (ufc).

A estimativa de 'ufc' para verificar a sensibilidade do teste ELISA foi realizada em placa individual com 4 repetições por diluição, determinando-se uma bordadura entre cada diluição pipetada na placa para evitar possíveis contaminações. As placas em que as amostras das variedades cítricas foram avaliadas não constou das diluições em série para se evitar contaminações, mas deve-se destacar que essas amostras foram submetidas às mesmas condições de temperatura, soluções tampão e tempo de permanência nas soluções em cada etapa utilizadas para a avaliação de sensibilidade do teste ELISA.

O resultado médio da concentração da bactéria igual a 1,4 vez maior que o controle negativo $\left(1,5 \times 10^{4} \mathrm{ufc} / \mathrm{ml}\right)$, possibilita verificar que os valores obtidos no teste ELISA, para as variedades positivas quanto a presença da $X$. fastidiosa (Tabela 4), estão restritos a uma amplitude de concentração média entre $1,3 \times 10^{4} \mathrm{ufc} / \mathrm{ml}$ e $2,75 \mathrm{x}$ $10^{4} \mathrm{ufc} / \mathrm{ml}$. Estes resultados apresentam certa diferença com os dados obtidos por Minsavage et al. (1994), quando estudaram videiras infectadas com X. fastidiosa, verificando que o mínimo de concentração detectável de suspensões de $X$. fastidiosa, pelo teste ELISA, encontrava-se em $1,3 \times 10^{5} \mathrm{ufc} / \mathrm{ml}$.

\subsection{Conclusões}

Os resultados obtidos nas condições em que o presente trabalho foi realizado permitem concluir:

1. O método de inoculação da bactéria $X$. fastidiosa influenciou nos resultados finais sobre a resposta da planta à presença do patógeno. 
2. A manutenção da fonte de inóculo (plantas contaminadas) experimentais, mantendo fluxo contínuo da bactéria $X$. fastidiosa, pode induzir resultados incorretos quanto à reação de hospedeiros.

3. O método de inoculação por suspensão bacteriana diretamente no caule da planta mostrou-se eficaz na infecção das variedades e espécies de Citrus estudadas.

4. Todas as variedades de laranja doce foram determinadas como suscetíveis à presença da $X$. fastidiosa.

5. Entre as 31 variedades e espécies estudadas não se verificou, independentemente do método de inoculação do patógeno, a presença da bactéria nas variedades de tangerina 'Ponkan', 'Satsuma', 'Mexerica do Rio', Citrus histrix e também no representante da espécie Poncirus trifoliata.

6 As variedades cidra 'Etrog', laranja 'azeda São Paulo' e tângelo 'Orlando' mostraram-se hospedeiros da bactéria.

7. Os testes PCR e ELISA foram adequados na detecção do patógeno.

8. Entre plantas serologicamente positivas, a variedade 'Hamlin' mostrou a maior concentração de bactéria depois de 12 meses da inoculação, seguida da 'Pera' IAC Premunizada e da laranja doce 'Natal'. 


\section{EFICIÊNCIA DE QUATRO MÉTODOS DE INOCULAÇÃO DE Xylella fastidiosa EM CITROS (Citrus spp.)}

\subsection{Resumo}

No estudo da relação patógeno-hospedeiro da $X$. fastidiosa são necessários métodos eficientes de inoculação em citros. Buscou-se, neste trabalho, comparar a eficiência de quatro métodos de inoculação da bactéria $X$. fastidiosa em laranja doce (Citrus sinensis L. Osbeck) (três clones de laranja 'Pêra': Pirangi, IAC 2000 e Ipiguá) e em tangerina 'Cravo' (C. reticulata Blanco). Os métodos de inoculação foram: A) encostia de mudas infectadas; B) enxertia de pecíolos infectados; C) garfagem lateral de ramos finos infectados e D) inoculação de suspensão bacteriana por meio de alfinete entomológico. $\mathrm{O}$ experimento foi constituído de 16 tratamentos com 4 repetições (uma planta por parcela), além dos tratamentos controle (plantas inoculadas com material sadio certificado e plantas não inoculadas). Avaliações mensais para presença de $X$. fastidiosa com PCR foram realizadas durante oito meses. Os percentuais de plantas de laranja doce infectadas para cada método de inoculação após a última avaliação foram: A) 66,67\%; B) 75,00\% \%; C) 50,00\%; D) 25,00\%. Todos os métodos foram eficientes na transmissão da bactéria para as plantas de laranja 'Pera'. No caso da tangerina 'Cravo', somente foi possível detectar o patógeno quando o método de inoculação utilizado foi o de suspensão bacteriana com alfinete entomológico, mas, mesmo assim, houve um decréscimo de $50 \%$ de plantas infectadas após 3 meses, sugerindo que esse grupo possa ser efetivamente resistente ao patógeno. 


\subsection{Summary: EFFICIENCY OF FOUR METHODS OF INOCULATION OF Xylella fastidiosa IN CITRUS}

In the study of the relationship pathogen-host of Xylella fastidiosa efficient methods of inoculation of bacteria in citrus are necessary. The present research work aimed to compare the efficiency of four methods of inoculation of the bacteria in sweet orange (Citrus sinensis) lines and mandarin (C. reticulata). The methods of inoculation were: A. approach of infected seedlings, B. petiole budding, C. grafting of young branches and $\mathrm{D}$. inoculation of bacterial suspension with needle. The plants tested were the selections Pirangi, IAC 2000 and Ipiguá of 'Pera' sweet orange and the 'Cravo' mandarin. The experiment comprised 16 treatments with 4 replications, being a plant per parcel plus the controls (plants inoculated with healthy certified material and not inoculated plants). Monthly evaluations with PCR were accomplished during eight months. The percentages of orange plants infected by each method were: $A=66,67 \%$; $=75,00 \% ; \mathrm{C}=50,00 \% ; \mathrm{D}=25,00 \%$. All methods were efficient in the transmission of the bacteria to the 'Pera' sweet orange plants. In the case of the 'Cravo' mandarin, the pathogen was detected only when the inoculation method used was $\mathrm{D}$, but even so there was a decrease of $50 \%$ of plants infected after 3 months, suggesting that this group can be indeed considered resistant to the pathogen. 


\subsection{Introdução}

A clorose variegada dos citros (CVC) é uma grave doença em fase de difusão generalizada e que contribui para a baixa produção da cultura dos citros no Brasil (Amaro et al., 1997). Esta doença foi constatada pela primeira vez em 1987 no município de Colina, situado no Estado de São Paulo e, desde então, sua ocorrência tem sido crescente e devastadora em diversos pomares e viveiros brasileiros (Tubelis et al., 1993; Borges et al., 2000).

O patógeno responsável por esta doença é a bactéria denominada Xylella fastidiosa Wells, gram-negativa, anaeróbica e restringe-se aos vasos do xilema da planta (Wells et al. 1987). Sua disseminação pode ocorrer por cigarrinhas vetoras e por propagação vegetativa, podendo atacar, além dos citros, diversas culturas econômicas tais como videiras, pessegueiros, cafeeiros, ameixeiras, entre outras (Hill \& Purcell, 1995).

Certas estirpes da $X$. fastidiosa parecem ter uma ampla gama de hospedeiros, incluindo espécies de pelo menos 28 famílias de plantas monocotiledônias e dicotiledôneas (Freitag, 1951; Holpkins, 1989; Raju et al, 1980; Wells et al.; 1987). Diversos trabalhos têm sido realizados com o intuito de verificar o comportamento de diferentes variedades de cada espécie de hospedeiro (Fry et al., 1990ab; Machado et al., 1997; Laranjeira et al., 1998ab; PESQUISA FAPESP, 2000). Para que esta relação Xylella-hospedeiros seja avaliada, diversos estudos científicos têm sido conduzidos visando determinar metodos de transmissão do patógeno tais como inoculação através de alfinetes com suspensào bacteriana produrida em meio de cultura (Holpkins, 1988; Fry et al., 1990), enxertia de materiais contaminados em plantas sadias ou "vice-versa" (Machado et al., 1997; Li, 1997) e encostia de mudas infectadas produzidas pela enxertia de ramos de laranjeiras adultas com CVC em "seedlings" de limão 'Cravo' (Medina et al., 1998).

O conhecimento de métodos eficientes de inoculação que permitam a avaliação do comportamento de diferentes variedades e até mesmo de hospedeiros alternativos de $X$. fastidiosa é fundamental para o desenvolvimento de novas pesquisas 
com esse patógeno. Um método eficiente, rápido e de baixo custo pode reduzir esforços que conseqüentemente se direcionarão para fatos ainda desconhecidos na luta contra a bactéria da CVC. Buscou-se, neste trabalho, comparar a eficiência de quatro métodos de inoculação da bactéria $X$. fastidiosa em laranja doce e tangerina.

\subsection{Material e métodos}

$\mathrm{O}$ experimento foi condurido em túnel plástico e em canteiros da área experimental do Departamento de Produção Vegetal da Universidade de São Paulo (USP/ESALQ), em Piracicaba, SP. Mudas cítricas sadias de três diferentes clones de laranja 'Pera' ( $C$. sinensis) (Pirangi, Ipiguá e IAC-2000)' e de tangerina 'Cravo' ( $C$. reticulata) enxertadas em limão 'Cravo' ( $C$. limonia) foram produzidas a partir de sementes e borbulhas provenientes do Banco Ativo de Germoplasma (BAG) do Centro de Citricultura 'Sylvio Moreira', em Cordeirópolis, SP.

Durante 18 meses, as referidas mudas foram cultivadas sob túnel plástico, com temperatura média de $26,3^{\circ} \mathrm{C}$, ou seja, dentro da faixa considerada adequada para o crescimento vegetativo de citros, $\left(25 \mathrm{a} 31^{\circ} \mathrm{C}\right)$, conforme Ortolani et al. (1991).

As plantas testes foram mantidas em vasos do tipo "Citrus pot" $(3,8$ litros) com substrato à base de areia, terra e plantimax para citros (1:1:1), dispostos sobre bancadas de madeira, a 1,5 m de altura em relação ao chão.

Todo material utilizado como fonte de inóculo de $X$. fastidiosa, nos métodos testados, foi proveniente de uma única planta cítrica, descrita aqui como doadora, da variedade laranja 'Valência' (Citrus sinensis Osbeck), enxertada em limão 'Cravo', localizada na Fazenda São Jorge, em Colina, SP. A escolha dessa planta doadora baseou-se na deteç̧ão prévia da CVC a partir da simples visualização dos sintomas e pela identificação da bactéria através do teste molecular PCR. As plantas experimentais foram infectadas com X. fastidiosa em março de 1999, sendo que nesta época as variedades copa enxertadas apresentavam 9 meses de idade.

Os métodos de inoculação testados, quanto à eficiência na transmissão do patógeno, foram os seguintes: a. encostia de mudas infectadas; b. enxertia de pecíolos 
infectados; c. garfagem lateral de ramos finos e; d. suspensão bacteriana introduzida por alfinetes entomológicos.

\section{Encostia de mudas infectadas}

$\mathrm{O}$ método de inoculação por encostia de mudas infectadas trata-se da união de uma muda cítrica doente com outra sadia após ser feita uma raspagem na casca das hastes das plantas para facilitar a troca da seiva e conseqüente união das mesmas. $\mathrm{Na}$ produção das mudas cítricas, que serviram de fonte de inoculo, utilizaram-se "seedlings" de limão 'Cravo' sadios com 6 meses de idade, produzidos em tubetes. Esses "seedlings" foram subenxertados em ramos de laranjeira 'Valência' no campo infectada pela bactéria e mantidos em contato com a planta mãe por 50 dias. Após este período, as mudas formadas com a combinação copa-cavalo de limão 'Cravo' com laranja 'Valência' hospedeira da CVC foram então enxertadas por encostia nas mudas receptoras experimentais.

\section{Enxertia de peciolos infectados}

Pecíolos de folhas sintomáticas da CVC foram selecionados e extraídos da planta doadora infectada. $\mathrm{O}$ caule das mudas de citros foi enxertado com o pecíolo infectado a $15 \mathrm{~cm}$ acima da região de união copa-cavalo. $O$ processo utilizado nesta enxertia foi baseado segundo os procedimentos convencionais de enxertia para citros (" $\mathrm{T}$ " invertido), sendo o pecíolo colocado em íntimo contato com o câmbio da planta receptora $e$, antes da enxertia, feita a raspagem dos tecidos para facilitar a união e a liberação da seiva infectada com a $X$. fastidiosa. A escolha do pecíolo para a transmissão da bactéria baseou-se no fato de que o patógeno tende a se concentrar em maior quantidade nessa região da planta (Fry \& Milholland, 1990).

\section{Garfagem lateral de ramos finos}

Descrita por Li (1997), trata-se de uma técnica de simples execução. Ramos finos e doentes, com $15 \mathrm{~cm}$ e 4 gemas, foram retirados da planta doadora e enxertados na haste principal das mudas sadias, por garfagem. 
Suspensão bacteriana introduzida por alfinetes entomológicos

A bactéria foi isolada em meio de cultura BCYE (Wells et al, 1981) com 45 dias de antecedência da inoculação, sendo repicada duas vezes a cada quinze dias e mantida a uma temperatura de $28^{\circ} \mathrm{C}$ antes de ser diluída em solução tampão SCP (succinate-citrate-phosphate). A leitura de densidade ótica da solução tampão contendo $X$. fastidiosa foi realizada em espectrofotômetro $(600 \mathrm{~nm})$ e revelou absorbância de 0,6. A inoculação da bactéria foi realizada no horário entre $11 \mathrm{~h}$ e $12 \mathrm{~h}$ para otimizar a absorção da solução tampão pela planta. Ramos com brotações novas foram selecionados e marcados com fitas numeradas para identificar o local da inoculação e a posição da folha a ser amostrada na avaliação. Uma gota da solução tampão contendo $X$. fastidiosa foi colocada na brotação marcada com auxílio de um conta-gotas. Em seguida, um furo foi realizado com o alfinete entomológico no local onde a gota foi depositada para facilitar a introdução da bactéria na planta.

O experimento foi conduzido em delineamento inteiramente casualizado, com 16 tratamentos (4 métodos de inoculação em mudas de 4 variedades de citros), com 4 repetições e uma planta por repetição.

O experimento constou também de dois tratamentos controle conforme segue:

1. Os tratamentos foram repetidos com os mesmos procedimentos de inoculação, porém, sem a presença do patógeno;

2. Tratamentos com mudas sadias representantes das quatro variedades.

Para a avaliação da presença da bactéria da CVC, após inoculação, quatro folhas das plantas receptoras de cada tratamento foram coletadas. Essas folhas foram retiradas próximas ao local de inoculação na planta. As amostragens mensais foram realizadas durante oito meses, após 60 dias da inoculação .

Todas as amostragens foram realizadas apenas com um dia de antecedência da extração do DNA, necessária para as avaliações laboratoriais de detecção da bactéria. Desta forma, após as amostragens, as folhas de cada parcela 
experimental foram acondicionadas em sacolas plásticas e armazenadas em câmara fria $\left(2^{\circ} \mathrm{C}\right)$ aguardando as análises.

A determinação da presença da bactéria $X$ : fastidiosa foi realizada pelo teste molecular PCR ("Polymerase Chain Reaction"), no laboratório de Biotecnologia do Centro de Citricultura "Sylvio Moreira" do IAC, em Cordeirópolis, SP.

Teste PCR para detecção da X. fastidiosa

$\mathrm{Na}$ extração do DNA, pecíolos das folhas amostradas $(250 \mathrm{mg})$ foram triturados em nitrogênio líquido até transformação em pó. Já na forma de pó, cada amostra foi distribuída em 2 tubos eppendorfs $(1,5 \mathrm{ml})$ previamente identificados. $\mathrm{O}$ processo de extração do DNA ocorreu adicionando-se $1,8 \mathrm{ml}$ de tampão de extração CTAB-Sarcosyl (1\% do CTAB; $100 \mathrm{mM}$ de Tris-HCI pH 7,5; $10 \mathrm{mM}$ de EDTA; 0,7 M do $\mathrm{NaCI} ; 2 \%$ de Sarcosyl; $140 \mathrm{mM}$ de 2-mercaptoetanol) em cada amostra contida nos. tubos. Os tubos foram incubados por 35 minutos em banho-maria a $60{ }^{0} \mathrm{C}$, sendo agitados 3 a 4 vezes nesse período e depois deixados para esfriar em temperatura ambiente. Após este esfriamento, um volume de clorofórmio (álcool isoamílico 24:1) foi adicionado aos tubos e então foram levemente agitados por 100 vezes. Após esse processo, as amostras foram centrifugadas a $12000 \mathrm{rpm}$ por 5 minutos quando se procedeu a transferência da fase superior de cada tubo para outros tubos Eppendorf. Nesta etapa, foi adicionado 0,1 volume de CTAB 10\% (10\% de CTAB; 0,7 M do NaCI) com outro volume de clorofórmio (álcool isoamílico), seguido de 100 leves agitações e de 8 minutos de centrifugação a $12000 \mathrm{rpm}$. Transferiu-se novamente a fase superior para outros tubos eppendorfs. Foi então adicionado um volume do tampão de precipitação $\mathrm{CTAB}$, sendo este misturado cuidadosamente ao material obtido na fase superior e deixado por 15 a 30 minutos em repouso. Uma nova centrifugação foi realizada a $10000 \mathrm{rpm}$ por 5 minutos, sendo descartados os sobrenadantes. $\mathrm{O}$ sedimento

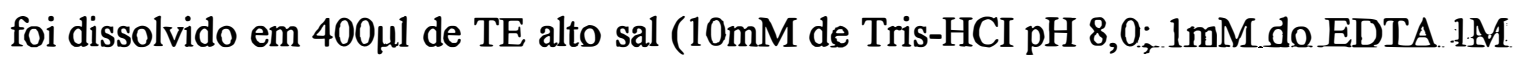
de $\mathrm{NaCl}$ ) em banho-maria a $60{ }^{\circ} \mathrm{C}$ até total dissolução. O DNA foi precipitado adicionando-se dois volumes de etanol absoluto gelado e, em seguida, centrifugado por 10 minutos a $12000 \mathrm{rpm}$ em centrífuga refrigerada a $4{ }^{\circ} \mathrm{C}$. Removeu-se o sobrenadante e 
o precipitado foi lavado por duas vezes; a primeira com $700 \mu \mathrm{l}$ de etanol $70 \%$ (centrífuga por 5 minutos) e a segunda com $400 \mu$ de etanol 100\% (centrifuga por 5 minutos). Logo depois, o DNA foi seco por inclinação do sobrenadante e dissolvido o "pellet" em $20 \mu \mathrm{l}$ de TE $1 / 10+$ RNAse por 1 hora a $37^{\circ} \mathrm{C}$.

Reação de amplificação do DNA - PCR

A amplificação do DNA foi realizada com volume de $25 \mu \mathrm{l}$, sendo $2,5 \mu \mathrm{l}$ de tampão 10X (100mM de Tris-HCl pH 8,3; 500mM de KCI; $25 \mathrm{mM}$ de $\mathrm{MgCl}_{2}$ e $0,01 \%$ de gelatina), $1 \mu \mathrm{l}$ de dinucleotídeos, $0,5 \mu \mathrm{l}$ de cada "primer" (12,5ng) e 0,3 $\mu \mathrm{l}$ de Taq polimerase, completando finalmente o volume com água bidestilada. Os "primers" utilizados foram os descritos por Pooler \& Hartung (1995): CVC P2 (5' AGATGAAAACAATCATGCAAA 3') e $\quad$ CVC P1

GCCGCTTCGGAGAGCATTCCT 3'). O programa utilizado no termociclador também foi_descrito por Pooler \& Hartung_(1995), sendo 1 minuto a $94^{\circ} \mathrm{C}$ para_desnaturação,_. 1 minuto a $60{ }^{\circ} \mathrm{C}$ para anelamento; 2 minutos a $72{ }^{\circ} \mathrm{C}$ para extensão, 10 minutos a $70^{\circ} \mathrm{C}$ para extensão final por 30 ciclos. A visualização das reações foi feita em gel de agarose a 1\%, diluído em tampão TAE 50X ( $1 \mathrm{ml}$ do tampão para $50 \mathrm{ml}$ de água destilada) e corado com brometo de etídeo ( $4 \mu \mathrm{l}$ por $100 \mathrm{ml}$ de gel). As reações especificas para $X$. fastidiosa, causadora da CVC, foram detectadas na região de 500 pares de bases.

\subsection{Resultados e discussão}

Os resultados referentes à presença de $X$. fastidiosa nas plantas experimentais avaliadas pelo teste molecular PCR, indicativos da eficiência dos métodos de inoculação, são apresentados nas Tabelas 5 e 6.

Todas as mudas cítricas inoculadas por enxertia de materiais infectados pela bactéria apresentaram $100 \%$ de êxito no pegamento do enxerto, resultado esse em desacordo com o relato de Machado et al. (1997) que verificaram problemas de baixo 
pegamento do enxerto devido à presença do patógeno responsável pela doença Clorose Variegada dos Citros.

A variedade tangerina 'Cravo' não se mostrou um hospedeiro favorável para a $X$. fastidiosa, não sendo detectada a sua presença nas mudas inoculadas pelos métodos de encostia, garfagem de ramos finos e pecíolo quando se aplica o teste PCR (Tabela 5). A exceção ocorreu com o método da suspensão bacteriana introduzida por alfinete entomológico, que mostrou eficiênçia na inoculação da bactéria, com $50 \%$ das plantas infectadas, embora não induzindo sintomas da doença. Essas reações específicas, verificadas pelo teste PCR, indicando a presença da bactéria da CVC nas mudas de tangerina 'Cravo', mostram que, além do método de inoculação por suspensão bacteriana ser eficiente, também são resultados que apontam para a tangerina 'Cravo' como um possível hospedeiro da $X$. fastidiosa, discordando das afirmações de Laranjeira et al (1998a) que relataram ser a tangerina 'Cravo' um cultivar não hospedeiro da $X$. fastidiosa. No caso da laranja 'Pera', todas as três seleções mostraram ser hospedeiras e com expressão de sintomas após períodos de espera que variaram de acordo com a seleção e com o método de inoculação utilizado (Tabela 6.).

Tabela 5. Número de mudas de tangerina 'Cravo' de um total de 4 plantas por tratamento, infectadas com a bactéria $X$. fastidiosa em março de 1999; através de 4 métodos de inoculação e avaliadas durante 8 meses pelo teste molecular PCR. Piracicaba-SP, 1999.

\begin{tabular}{|c|c|c|c|c|c|c|c|c|c|}
\hline \multirow[t]{2}{*}{ Métodos de inoculação } & \multicolumn{8}{|c|}{ Número de plantas infectadas (1999) } & \multirow{2}{*}{$\begin{array}{l}\text { \% deptantas } \\
\text { positivas }\end{array}$} \\
\hline & Maio & Jun. & Jur. & Ágos. & Set. & Out. & Nov. & Dez. & \\
\hline $\begin{array}{l}\text { Encostia de mudas } \\
\text { infectadas }\end{array}$ & 0 & 0 & 0 & 0 & 0 & 0 & 0 & 0 & 0 \\
\hline $\begin{array}{l}\text { Suspensão bacteriana } \\
\text { introduzida por alfinetes } \\
\text { entomológicos }\end{array}$ & 2 & 0 & 2 & 2 & 2 & 2 & 2 & 2 & 50 \\
\hline $\begin{array}{l}\text { Garfagem lateral de ramos } \\
\text { finos }\end{array}$ & 0 & 0 & 0 & 0 & 0 & 0 & 0 & 0 & 0 \\
\hline $\begin{array}{l}\text { Enxertia de pecíolos } \\
\text { infectados }\end{array}$ & 0 & $0^{-}$ & 0 & 0 & 0 & 0 & 0 & 0 & 0 \\
\hline
\end{tabular}


Considerando os resultados da Tabela 6, observa-se que todos os métodos de inoculação avaliados transmitiram a bactéria para as plantas cítricas, confirmando os resultados obtidos por Fry \& Milholland (1990), Lee et al. (1991), e Medina et al. (1998) que avaliaram a reação de plantas a $X$. fastidiosa, utilizando um ou outro dos métodos de transmissão do patógeno estudados aqui, sem todavia, comparar e identificar o mais eficiente entre eles.

Tabela 6. Número de mudas de três seleções de laranja 'Pera' de um total de 4 plantas por tratamento, infectadas com a bactéria $X$. fastidiosa em março de 1999 , através de 4 métodos de inoculação e avaliadas durante 8 meses pelo teste molecular PCR. Piracicaba-SP, 1999.

\begin{tabular}{|c|c|c|c|c|c|c|c|c|c|c|}
\hline \multirow{2}{*}{$\begin{array}{l}\text { Métodos de } \\
\text { inoculaçãe }\end{array}$} & \multirow{2}{*}{$\begin{array}{l}\text { Seleção } \\
\text { inoculada }\end{array}$} & \multicolumn{8}{|c|}{ Número de plantas infectadas pela bactéria e sintomáticas * } & \multirow{2}{*}{$\begin{array}{c}\text { \% de } \\
\text { plantas } \\
\text { positivas }\end{array}$} \\
\hline & & maio/99 & jum/99 & $\mathrm{jul} / 99$ & agos $/ 99$ & set/99 & out/99 & nov/99 & der/99 & \\
\hline \multirow{4}{*}{$\begin{array}{l}\text { Encostia de } \\
\text { mudas } \\
\text { infectadas }\end{array}$} & Pirangi & 0 & 2 & 2 & 3 & 3 & 3 & 3* & $-3^{*}$ & 75 \\
\hline & Ipiguá & $\theta$ & 2 & 2 & 2 & 3 & 3 & $3 *$ & $3 *$ & 75 \\
\hline & IAC2000 & 0 & 1 & 1 & 2 & 2 & 2 & 2 & $2^{*}$ & 50 \\
\hline & & & & & & & & Total & 8 & 66,67 \\
\hline \multirow{4}{*}{$\begin{array}{l}\text { Suspensão } \\
\text { bacteriana } \\
\text { introduzida } \\
\text { por alfinetes } \\
\text { entomológicos }\end{array}$} & Pirangi & $\theta$ & 1 & 1 & 1 & 1 & 1 & 1 & 1 & 25 \\
\hline & Ipiguá & 0 & 0 & 1 & 1 & 1 & 1 & 1 & 1 & 25 \\
\hline & IAC2000 & 0 & 0 & 0 & 1 & 1 & 1 & 1 & 1 & 25 \\
\hline & & & & & & & & Tóal & 3 & 25,00 \\
\hline \multirow{4}{*}{$\begin{array}{l}\text { Garfagem } \\
\text { lateral de } \\
\text { ramos finos }\end{array}$} & Pirangi & 0 & 2 & 2 & 3 & 3 & 3 & $3^{*}$ & 3* & 75 \\
\hline & Ipigua & 0 & $\theta$ & 0 & 1 & 2 & 2 & 2 & $2 *$ & 50 \\
\hline & IAC 2000 & 0 & 0 & 0 & 1 & 1 & 1 & 1 & 1 & 25 \\
\hline & & & & & & & & Total & 6 & 50,00 \\
\hline \multirow{4}{*}{$\begin{array}{l}\text { Enxertia de } \\
\text { pecíolos } \\
\text { infectados }\end{array}$} & Pirangi & 0 & 2 & 2 & 3 & 3 & 3 & $3^{*}$ & $3^{*}$ & 75 \\
\hline & Ipigua & 0 & 2 & 2 & 2 & 4 & $4 *$ & 4 & $4 \%$ & 100 \\
\hline & IAC2000 & 0 & 0 & 0 & 1 & 2 & 2 & 2 & $2^{*}$ & 50 \\
\hline & & & & & & & & Total & 9 & 75,00 \\
\hline
\end{tabular}

Obs: $*=n^{o}$ de plantas com sintomas da CVC.

Nas avaliações com a laranja 'Pera' (Tabela 6), o melhor resultado foi obtido no método de inoculação por enxertia de pecíolo que comparativamente mostrouse mais eficiente entre os quatro métodos estudados, resultando na transmissão do 
patógeno em 75\% das mudas avaliadas. Além da alta porcentagem de infecção, este método justifica sua utilização pela facilidade na aquisição do material infectante e na execução da técnica.

Li (1997) comparou alguns métodos de inoculação da bactéria da CVC através da enxertia de materiais propagativos infectados. Contudo, deve-se destacar a necessidade de se dispor de uma técnica simples e de baixo custo como é o caso da enxertia de pecíolo infectado que, além de apresentar grande eficiência na transmissão do patógeno, permite fornecer informações seguras sobre o nível de resistência_-da variedade da planta ao patógeno. É fato que cuidados especiais devem ser tomados quando o método de inoculação da bactéria da CVC apresentar uma fonte de inóculo constante. $\mathrm{O}$ permanente acesso do patógeno à planta pode induzir a conclusões errôneas se o objetivo for determinar se uma variedade é hospedeira ou não do patógeno.

$\mathrm{O}$ método de encostia de mudas doentes foi o segundo mais eficiente, com 65,67\% de mudas infectadas (Tabela 6), concordando com o relato de Medina et al. (1998) que obtiveram bons resultados de transmissão da bactéria da CVC através desse método. Plantas cítricas infectadas foram observadas quatro meses após a inoculação por encostia, mostrando que o contínuo fluxo de seiva permite que a bactéria tenha um acesso rápido aos tecidos sadios, havendo, contudo, interferência da época do ano devido a amplitudes térmicas que parecem afetar diretamente no desenvolvimento do patógeno. Este método, apesar de ser eficiente na transmissão da doença apresenta algumas dificuldades, como por exemplo a demora na produção da fonte de inóculo que exige até 3 meses para obtenção. Outro fato é certamente a necessidade de mão-de-obra especializada, para a produção das mudas com a presença do patógeno.

Segundo os resultados apresentados, foi possível verificar ainda que a metodologia de inoculação por enxertia de garfos de ramos finos coletados de árvores doentes, conforme é descrito por Li (1997), também pode ser utilizada para avaliar a resistência ou tolerância de variedades copa de citros à infecção da bactéria $X$. fastidiosa, sendo que a taxa de infecção avaliada nas três seleções de laranja doce 'Pera', atingiu $50 \%$ das mudas em 8 meses após a enxertia com os ramos doentes. 
Ainda na Tabela 6, observa-se que o método de inoculação por agulha entomológica com extrato da bactéria apresentou resultado 3 meses após a inoculação, mas com reduzida eficiência ${ }_{2}$ discordando dos dados de Almeida (1999). Segundo o pesquisador, a inoculação por este método possibilita a detecção da bactéria por PCR após um mês da inoculação em "seedlingș" de citros. Possivelmente, as diferenças de idade das plantas experimentais e suas características juvenis podem explicar o desacordo nos resultados dos dois estudos.

A bactéria não foi detectada nas plantas dos controles sadios, independentemente do tipo de tratamento utilizado. Não foram observadas alterações visuais fisiológicas ou nutricionais nas plantas controles submetidas às diferentes técnicas de inoculação, sem a presença do patógeno.

\subsection{Conclusões}

Os dados obtidos no presente experimento permitem enunciar-se as conclusões a seguir:

1. O método de inoculação utilizando a enxertia de pecíolos de folhas de árvores com CVC mostrou-se o mais eficiente e adequado para a infecção experimental da bactéria.

3. O uso de alfinete para introdução da solução bacteriana mostrou ser pouco eficiente na inoculação de $X$. fastidiosa.

4. Os métodos de inoculação por garfagem lateral de ramos finos e encostia de plantas jovens contaminadas mostraram eficiência intermediária.

5. As três seleções de laranja 'Pera' estudadas mostraram comportamentos similares no experimento, apresentando-se como hospedeiras favoráveis da bactéria. 
6. A tangerina 'Cravo', embora sem expressar sintomas de $\mathrm{CVC}_{2}$ mostrou ser hospedeira da $X$. fastidiosa. 


\section{CONCLUSÕES}

De acordo com os resultados obtidos nos trabalhos experimentais, pode-se concluir que:

1. A manutenção da fonte de inóculo (plantas contaminadas) experimentais, mantendo fluxo contínuo da bactéria $X$. fastidiosa, pode induzir resultados incorretos quanto à reação de hospedeiros.

2. Todas as variedades de laranja doce foram determinadas como suscetíveis à presença da $X$. fastidiosa, havendo exceção apenas para a laranja doce 'Westin' quando o método de inoculação foi o de introdução de suspensão bacteriana no tronco da planta.

3. Entre as 31 variedades e espécies estudadas não se verificou, independentemente do método de inoculação do patógeno, a presença da bactéria nas variedades de tangerina 'Ponkan', 'Satsuma', 'Mexerica do Rio', Citrus histrix e também no representante da espécie Poncirus trifoliata.

4. As variedades cidra 'Etrog', laranja 'Azeda São Paulo' e tângelo 'Orlando' mostraram-se hospedeiros tolerantes à bactéria, devido à baixa concentração do patógeno detectada por ELISA e ausência de sintomas característicos da doença CVC.

5. Entre plantas serologicamente positivas, a variedade 'Hamlin' mostrou a maior 
concentração de bactéria depois de 12 meses da inoculação, seguida da 'Pera IAC Premunizada' e da laranja 'Natal'.

6. O método de inoculação mais eficiente e adequado para a infecção experimental da bactéria $X$. fastidiosa em variedades cítricas testes, foi o de enxertia de pecíolos de folhas de árvores com a CVC, e o menos eficiente, o método de introdução da suspensão bacteriana por alfinete.

7. A tangerina 'Cravo', embora sem expressar sintomas de CVC, mostrou ser hospedeira da $X$. fastidiosa quando inoculada pelo método da introdução de suspensão bacteriana com alfinete entomológico. 


\section{REFERÊNCIAS BIBLIOGRÁFICAS}

AGARWAL, P.K. Cytomorphology of nine species of citrus. In: INTERNATIONAL CITRUS CONGRESS, 7., Acireale, 1992. Proceeding. Acireale: International Society of Citriculture, 1992. P. 346-352.

AGRIANUAL 99. Anuário estatístico da Agricultura Brasileira. FNP - Consultoria e comércio. São Paulo, 481p., 1999.

AMARO, A.A. Citricultura. Informações Econômicas, v.29, n. 12, p. 1-12, 1999.

AVRAMEAS, S. Coupling of enzymes to proteins with glutaraldehyde. Use of the conjugates for the detection of antigens and antibodies. Immunochemistry, v.6, n. 43-52, 1969.

BAINES, R.C.; CAMERON, J.W.; SOOST, R.K. Four biotypes of Tylenchulus semipenetrans in California identified and their importance in the development of resistant citrus rootstocks. Journal of Nematology, v.6, n.2, p. 63 -66, 1974.

BARRETT, H.C.; RHODES, A.M. A numerical study of affinity relationships in cultivated Citrus and its close relatives. Systematic Botany, v.1, p.105-36, 1976.

BERETTA, M..J.G.; ROSSETI,V.; TELXEIRA, A.R.R.; SEMPIONATO, O. Positive diagnosis list for decline on plants root-graft inoculated in Brazil. In: CONFERENCE OF THE INTERNATIONAL ORGANIZATION OF CITRUS VIROLOGISTS, 11., Riverside, 1991. Proceedings. Riverside: IOCV, 1991. p.256-260.

BERETTA, M.J.G.; COELHO, R.C.S.; LEAL, A.M.B.; GAMA, T.T.; LEE, R.F.; DERRICK, K.S. Tahiti lime is tolerant to citrus variegated chlorosis. Fitopatologia Brasileira, v. 18, p.277, 1993. 
BERETTA, M..J.G. Avaliação de transmissão e seleção de variedades a Clorose Variegada dos Citros (II). Revista Laranja, v.14, n.1, p.167-176, 1993.

BERETTA, M.J.G.; HARAKAWA, R.; DERRICK, K.S.; LEE, R.F; LARANJEIRA, F.F. The distribution of Xylella fastidiosa in citrus variegated chlorosis-affected trees. In: CONFERENCE OF THE INTERNATIONAL ORGANIZATION OF CITRUS VIROLOGISTS, 13., Riverside, 1996. Proceedings. Riverside: IOCV, 1996. p.376-377.

BERETTA, M.J.G.; BARTHE, G. A.; CECCARDI, T. L.; LEE, R. F.; DERRICK, K. S. A survey for strains of Xylella fastidiosa in citrus affected by citrus variegated chlorosis and citrus blight in Brazil. Plant Disease, v. 81, p.1196-1198, 1997.

CARLOS, E.F.; RODRIGUES NETO, J.; BERETTA, M.J.G. A bactéria Xylella fastidiosa. In: DONADIO, L.C.; MOREIRA, C.S. Clorose variegada dos citros. Bebedouro: Fundecitrus, 1997. cap.2, p. 22-33.

CARVAIHO, M.L.V., ROSSETTI, V.; POMPEU JUNIOR, J. Evoluçao da sintomatologia de clorose variegada dos citros em laranja doce (Citrus sinensis), Fitopatologia Brasileira, v.20, p.351, 1995.

CASTRO, P.R.C.C. Aspecto fisiológico do amarelinho. In: Encontro técnico sobre amarelinho dos citros, 1992, Piracicaba, p.24-26.

CHANG, C.J.; GARNIER, M.; ZREIK, L.; ROSSETI, V.; BOVÉ, J.M. Citrus variegated chlorosis: cultivation of the causal bacterium and experimental reproduction of disease. Proceedings of $12^{\text {th }}$ International Organization of Citrus Virologist Congress, 1993, 294-300.

CHEN, C.; CHANG, C. J.; JAEEWT, R. L; GAWEL, N. Genetic variation among Xylella fastidiosa strains. Phytopathology, v. 82, p. 973-977, 1992.

CHEN, J.; LAMIKANRA, O.; CHANG, C. J.; HOPKINS, D. L. Randomly amplified polymorphic DNA analysis of Xylella fastidiosa Pierce's disease and Oak leaf scorch pathtypes. Applied of Envirommental Microbiology, v.61, n.1, p.1688-1690, 1995.

CLARK, M.F.; ADAMS, A. N. Characteristics of the microplate method of enzyme- 
linked inimunosorbent assay for the detection of plant viruses. Journal Genetical Virology, v. 34, p.475-483, 1977.

COLETTA FILHO, H.D.; CARLOS, E.F.; MACHADO, M.A. Distribuição da bactéria XyIella fastidiasa em plantas de laranja. Fitopatologia Brasileira, n.22 suplemento, p.234, 1997.

CONVERSE, R. H.; MARTIN, R.R. Elisa Methods For Plant Viruses. In: HAMPTON, R; BALL, E.; DE BOER, S. (Ed.) Serological methods for detection and identification of viral and bacterial plant pathogens. St. Paul, Minnesota: APS Press, 1990. Section IV, p.179-196.

COSTA, A.S.; SILVÉRIO, J.L.; GUIRADO, N.; MÜLLER, G.W. Sintomas da deficiência de molibdênio podem ser parte da resposta da planta infestada a' clorose variegada dos citros. Fitopatologia Brasileira, v.17, n.2, p.10, 1992.

DA COSTA, P.I.; FRANCO, C.F.; MIRANDA, V.S.; TEIXEIRA, D.C.; HARTUNG, J.S. Strains of Xylella fastidiosa rapidly distinguished by arbitrarily primed-PCR. Current Microbiology, v.40, p.279-282, 2000.

DAVIES, F.; ALBRIGO, L.G. Taxonomy, cultivars and breeding. In: GMITTER Jr., F G.; GROSSER, J.W.; MOORE, O. A. Citrus. Wallingford: CAB International, cap.2, p.12-51, 1994.

DE NEGRI, J.D. Clorose variegada dos citros: uma nova anomalia afetando pomares em São Paulo e Minas Gerais. Comunicado Técnico. n 82 Extensão Rural, Cati, Campinas, 6p., 1990.

DONADIO, L.C. Avaliação de três substratos para semeadura de porta-enxertos para citros em bandejas. Revista Brasileira de Fruticultura., v.13, p.67-73, 1991.

DU CHARME, E.P. Resistance of Poncirus trifoliata rootstock to nematode infestion in Argentina. Citrus Industry, v.29, n.7, p.9-15, 1948.

FEDER, W.A. Differential susceptibility of selection of Poncirus thfofiata to attack by the citrus nematode Tylenchulus semipenetrans. Israel Journal Agriculture Research, v. 18, n.4, p.175-9, 1968. 
FERREIRA, M.E.; @RATTAPAGLIA, D. Introdução ao uso de marcadores RAPD e RFLP em análise genética. Brasilia: EMBRAPA-CENARGEN, 1995. p.220

FRENCH, W.J.; CHRISTIE, R.G.; SLASSI, D.L. Recovery of rickettsialike bacteria vacuun infiltration of peach tissues affected with phony disease. Phytopathology, v.65, p.945-948, 1977.

FREITAG, J.H. Host of the Pierce's disease virus of grapes as determinated by insect transmission. Phytopathology, v.41, p. 920-934, 1951.

FRY, S.M.; MILHOLLAND, R.D. Multiplication and translocation of Xylella fastidiosa in petioles and stems of grapevine resistant, tolerant and susceptible to Pierce's disease. Phytopathology, v.80, p. 61-65, 1990a.

FRY, S.M.; MILHOLLAND, R.D. Response of 'resistant, tolerant and susceptible grapevine tissues to invasion by the Pierce's disease bacterium, Xylella fastidiosa. Phytopathology, v.80, p. 66-69, 1990b.

FUNDECITRUS Levantamento mostra que doença se estabiliza e sintomas se agravam. Revista do FUNDECITRUS. n.99, jul/ago, 2000

GARNIER, M.; CHANG, C.J.; ZREIK, L.; ROSSETTI, V.; BOVÉ, J.M. Citrus variegated chlorosis: serological detection of Xylella fastidiosa, the bacterium associated with the disease, p. 301-305. In: Proceeding 12th Conference IOCV. IOCV, Riverside. 1993.

GARNIER, M.; BOVÉ, J.M. Recent developments in vascular-restricted, walled bacteria of citrus: XyIelIa fastidiosa and the liberobacters, proteobacterial plant pathogens. Fruits, v.52, p.361-369, 1997.

GMITTER, F.G.; HU, X. The possible role of Yunnan, China, in the originof Contemporary Citrus species (Rutaceae). Economic Botany, v. 44, p. 267-277, 1990.

GOLINO, D.A. Disease induced by phloem- and xylem-limited prokaryotes. Pierce's disease. In: MARTELLI, G.P. Grafting-transmissible dieases of grapevines. Handbook for detection and diagnosis. Rome, Italy: Food and Agriculture Organization of the united nations, 1993. Part I, p.107-114. 
GOTTWALD, T.R.; GIDTTI, F.B.; SANTOS, I. M.; CARVALHO, A.C. Preliminary spatial and temporal analysis of citrus variegated chlorosis in Brazil p. 327 - 335 In: Proc. 12th Conference International Organization Citrus Virology Moreno, P., Da Graça, J. V. and Timmer, L.W., eds. IOCV, Riverside, CA, 1993.

GRAVENA, S.; LOPES, J.R.S.; PAIVA, P.E.B.; YAMAMOTO, P.T.; ROBERTO, S.R. Os vetores da Xylella fastidiosa. In: DONADIO, L.C.; MOREIRA, C.S. Clorose variegada dos citros. Bebedouro: Fundecitrus, 1997. Cap.2, p. 22-33.

HANDA, T.; ISHIZAWA, Y; OOGAKI, C. Phylogenetic study of fraction I protein in the genus Citrus and its close related genera. Japan Journal of Genetics, v.61, p.15-24, 1986.

HENSON, J.M; FRENCH, R. The polymerase chain reaction and plant disease diagnosis. Annual Review Phytopathology, v.31, p. 81-109, 1993.

HILL, B. L.; PURCELL, A.H. Acquisition and retention of Xylella fastidiosa by an efficient vector, Graphocephala atropanctata. Phytopathology, v.85, p.209-212, 1995.

HODGSON, R.W. Horticultural varieties of Citrus. In: Reuther, W.; Batchelor, L.D.; Webber, H.J. The Citrus Industry. Berkeley: University of California, 1967. cap. 4, p. 431-591.

HOLPKINS, D.L. Production of diagnostic symptoms of blight in citrus inoculated with Xylella fastidiosa. Plant Disease, v.72, p.432-435, 1988.

.HOLPKINS, D.L.; ADLERZ,W.C. Natural host of Xylella fastidiosa in Florida. Plant Disease, v.72, p.429-431, 1988.

HOLPKINS, D.L. Xylella fastidiosa: Xylem-limited bacterial pathogen of plants. Annual Review Phytopatholology, v.27, p.271-290, 1989

HUANG, P.Y; MILHOLLAND, R.D.; DAYKIN, M.E. Structural and morphological changes associated with the Pierce's disease bacterium in bunch and muscadine grape tissue. Phytopathology, v.76, p.1232-1238, 1986. 
JACOMINO, A.J.; MODESTO, J.C.; SALIBE, A.A. Sintomas de reação à clorose variegada dos citros (CVC) em tronco de diferentes espécies de citros. Fitopatologia Brasileira, 18 (Suplemento), agosto, 1993.

KHAN, A.; RIES, S. M.; PATAKY, J. K. Transmission of Erwinia stewartit through seed of resistant and susceptible field and sweet corn. Plant Disease, v.80, p. 398403, 1996.

KLOTZ, L.J.; BITTERS, W.P.; DEWOLFE, T.A.; GARBER, M.J. Orchard test of Citrus rootstocks for resistance to Phytophthora. California Citrograph, v. 53, n.2, p. 38, 55, 1967.

LARANJEIRA, F.F.; POMPEU JR, J.; HARAKAVA, R. Seleção de variedades resistentes e/ou tolerantes a Clorose Variegada dos Citros (CVC). Fitopatolologia Brasileira, v.20, p. 324, 1995.

LARANJEIRA, F. F.; POMPEU JUNIOR, J.; HARAKAVA, R.; FIGUEIREDO, J.O.; CARVALHO, S.A.; COLETTA FILHO, H. D. Cultivares e espécies cítricas hospedeiras de Xylella fastidiosa em condição de campo. Fitopatolologia Brasileira, v.23, n.2, p. 147-155, 1998a.

LARANJEIRA, F.F.; POMPEU JR., J.; GARCIA JR, A.; VIEIRA, M.; HARAKAVA, R.; BERETTA, M. J. G. Screening for tolerance of citrus to XyIeIIa faszıdiosa, the causal agent of citrus variegated chlorosis-CVC. Fruits, v. 53, p. 345-349, 1998 b.

LARANJEIRA, F.F.; PALAZZO, D. Determinação preliminar dos efeitos da Clorose Variegada dos Citros em características físico-químicas de frutos de laranja Natal. Fitopatologia brasileira, v.19, p.309, 1994. Suplemento

LEE, R.F.; DERRICK, K.S.; BERETTA, M.J.G.; CHAGAS, C.M.; ROSSETTI, V. Citrus variegated chlorosis: A new destructive disease of citrus in Brazil. Citrus Industry, v.72, p.12, 13, 15, 1991.

LEE, R.F.; BERETTA, MJ.G.; DERRICK, K.S.; HOOKER, M.E. Development of a serological assay for citrus variegated chlorosis, a new disease of citrus in Brazil. Proceeding Florida State Horticulture Science, p.32-35, 1992. 
LEE, R.F.; BERETTA, M.J.G.; HARTUNG, J.H.; HOOKER, M.E.; DERRIK, K.S. Citrus variegated chlorosis confimation of Xylella fastidiosa as the causal agent. Summa Phytopathologica, Jaboticabal, v.19, p.123-125, 1993.

LEITE, R.M.V.B.C., STALL, R.E., HOPKINS, D.L., MINSAVAGE, G.V. Caracterização de estirpes de Xylella fastidiosa através de analise de DNA genômico e plasmídeo. Summa Phytopathologica, Jaboticabal, v.19, p.46, 1993. (Resumo).

LEITE, R.M.B.C.; LEITE JUNIOR, R.P.; CERESINI, P.C. Hospedeiros alternativos de Xylella fastidiosa entre plantas invasoras de pomares de ameixeira com escaldadura da folha. Fitopatologia Brasileira, v.22, n. 1, p.54-57, 1997.

LI, W. Método de avaliação de resistência a clorose variegada dos citros. Laranja, Cordeirópolis, v.17, $\mathrm{n}^{\circ} 1, \mathrm{p} .55-66,1996$.

LI, W.B. Estudo de resistência ou tolerância à clorose variegada dos citros. Tese de Doutorado - Faculdade de Ciencias Agrarias e Veterinarias, Universidade Estadual Paulista, Jaboticabal. 1997. 107 p.

LI, W.; DONADIO, L.C.; HE, C.; SEMPIONATO, O. Métodos de avaliação de resistência à clorose variegada dos citros. Laranja, v.17, p.55-66, 1996.

LI, W.B; HE, C.X.; PRIA JR., W.D.; TEIXEIRA, D.C.; MIRANDA, V.S.; COSTA, P.I.; AYRES, A.J. Xylella fastidiosa em raizes do limoeiro cravo (C. limonia Osbeck) enxertado com laranjas doces $C$. sinensis (L.) Osbeck no campo: In: XXIII Congresso Paulista de Fitopatologia.Programas e resumo, Campinas, Brasil. p.285, 2000.

LIMA, J.E.O.; MIRANDA, V.S.; HARTUNG, J.S.; BRIANSKY, R.H.; COUंTINHO, A.; ROBERTO, S.R.; CARLOS, B.F. Coffee leaf scorch bacterium: Axenic culture, pathogenicity, and comparison with XyIelIa fastidiosa of citrus. Plant Disease, v.82, p.94-97, 1998.

LURO, F.; LAIGRET, F.; BOVE, J.M. Application of random amplified polymorphic DNA (RAPD) to Citrus genetic and taxonomy. Proceedings of the International Society of Citriculture, 1992

MACHADO, M.A.; SILVÉRIO, J.L.; BAPTISTA, C.R.; LARANJEIRA, F.F.; 
BERETTA, M.J.G. Avaliação de transmissão e seleção de variedades à Clorose Variegada dos Citros (CVC). Revista Laranja, v.14, n.1, p.167-176, 1993.

MACHADO, M.A.; TARGON, M.L.N.; SILVÉRIO, J.L.; BAPTISTA,C.R.; CARVALHO, S.A. Transmissão da clorose variegada dos citros (III) e seleção de espécies variegadas. Laranja, Cordeirópolis, v. 15, n¹, p.97-107, 1994.

MACHADO, M.A.; TARGON, M.L.P.N.; BERETTA, M.J.G.; LARANJEIRA, F.F.; CARVALHO, S.A. Detecção de Xylella fastidiosa em espécies e variedades de citros sobre-enxertadas em laranja Pera com clorose variegada dos citros (CVC) Fitopatologia Brasileira, v.22, n.1, p.30-77, 1997

MALAVOLTA, E.; PRATES, E.S. Em discussão, as causas de nova anomalia dos citros. Informativo Coopercitrus, $\mathrm{n}^{\circ} 43$, ano V, p. 19-22, 1990.

MALAVOLTA, E., PRATES, H.S. Alterações na composição mineral das folhas de pomares afetados pela anomalia "amarelinho" ou clorose variegada. Laranja. Cordeirópolis, v.12, p.315-329, 1991.

MALAVOlTA, E.; MALAVOLTA, M.L.; CABRAL, P.C.; PRATES, M.S.; VITTI, G.C. Nova anomalia dos Citros - Estudos Preliminares. Laranja, Cordeirópolis, v.11, nº 1, p. 15-38, 1990.

MALAVOLTA, E., PRATES, H.S., PINTO, W.B. da S. Levantamento e observações sobre o "amarelinho" ou "clorose variegada" dos citros. Laranja. Cordeirópolis, v.13, n.2, p.503-513,1992.

MALIK, M.N.; SCORA, R.W.; SOOST, A. K. Studies on the origin of the lemon. Hilgardia, Calif. Agric. Exp. Sta., v.42, n.9, p.36-82, 1974.

MEDINA, C.L;. NUNES, W.M.C; MACHADO, M.A.; MACHADO, E.C. Transmission of Xylella fastidiosa by spliced approach grafting. p.163 In: XIV Conference of IOCV. 14th Cong. IOCV. Programme \& Abstrate, Campinas, Brasil 1998.

MILLER, S.A.; JOAQUIM, T.R. Diagnostic techniques for plant pathogens. Biotechnology in Plant Disease Control, p.321-339, 1993.

MINSAVAGE，G.V.; THOMPSON, C.M.; HOLPKINS, D.L.; LEITE, R.M.V.B.; STALL, R.E. Development of a polymerase chain reaction protocol for detection of 
Xylella fastidiosa in plant tissue. Phytopathology, v.84, p.456-461, 1994.

MOLLENHAUER, H.H.; HOPKINS, D.L. Xylem morphology of Pierce's diseaseinfected grapevines with different levels of tolerance. Physiology Plant Pathology, v.9, p.95-100, 1976.

MOREIRA, C.S.; MOREIRA, S. História da citricultura no Brasil. In: Rodriguez, et al.

Citricultura Brasileira. 2 ed. Campinas: Fundação Cargill, 1991. v.1, p. 1-21.

MULLIS, K.; FALOONA, F.; SCHARF, S.; SAIKI, R.; HORN, G.; ERLICH, H. Specific enzymatic amplification of DNA in vitro: the polymerase chain reaction. Cold Spring Harbor Symp quant biol, v.51, p.263-273, 1986.

PESQUISA FAPESP, n.53, p.40-41, 2000.

POMPEU JUNIOR, J. Porta-enxertos para citros. Citricultura Brasileira. Campinas, v.1, p.281-296, 1980.

POMPEU JR., J.; LARANJEIRA, F.F.; HARAKAWA, R.; BERETTA, M.J.G. Primeira constatação de sintomas foliares de Clorose Variegada dos Citros (CYC) em tangerinas e híbridos de tangerina, Fitopatologia Brasileira. 19: 318.1994 (Abstract).

POOLER, M.R., HARTUNG, J.S. Genetic relationships among strains of XyIeIla fastidiosa from RAPD-PCR data. Current Microbiology, v.31, p.134-137, 1995.

PRIA JR., W.D.; LI, W.B.; TEIXEIRA, D.C.; MIRANDA, V.S.; DA SILVA, M.R.; AYRES, A.J. Clorose variegada dos citros diminui tamanho de sementes de laranja doce e afeta sua germinação. p.285 In: XXIII Congresso Paulista de Fitopatologia. Programas e resumos, Campinas, Brasil. 2000.

PURCELL, A.H. 1994. Cigarrinhas na cultura dos citros. In: SEMINÁRIO INTERNACIONAL DE CITROS, 3, 1994, Bebedouro. p. 195-209.

PURCELL, A.H.; SAUNDERS, S.R. Fate of Pierce's disease strains of XyIeIla fastidiosa in cammon riparian plants in California. Plant Disease, v.83, p.825-83, 1999.

PURCELL, A.H.; SAUNDERS, S.R.; HENDSON, M.; GREBUS, M.E.; HENRY, M.J. Causal role of XyIeIla fastidiosa in oleander leaf scorch disease. Phytopathology, v.89, n. 1, 1999. 
RAJU, B.C.; NOMÉ, S.F.; DOCAMPO, D.M.; GOHEEN, A.C.; NYLAND, G.; LOWE, S.K. Alternative hosts of Pierce's disease of grapevine that occur adjacent to grape growing areas in California. American Journal Enology Viticulture, v.31, p.144$148,1980$.

ROOSE, ML. Isozyme and DNA restriction fragment length polymorphisms in Citrus breeding and systematics. Proceedings of the International Society of Citriculture, 1988.

ROSSETTI, V.; DE NEGRI, J.D. Clorose variegada dos citros. Laranja, Cordeirópolis, v.11, n.1, p.1-14, 1990.

ROSSETTI, V.; GONZALEZ, M.A.; DONADIO, L.C. Histórico. In: DONADIO, L.C.; MOREIRA, C.S. Clorose variegada dos citros. Bebedouro: Fundecitrus, 1997. Cap.1, p. 1-21.

SALIBE, A.A. Curso de especialização em citricultura a nível de pós-graduação. Recife: SUDENE, 1969. 114p.

SALIBE, A.A.; ROESSING, C. Limitações no uso do Poncirus trifoliata como porta-enxerto para citros. Ciência Cultural, v.5, p.230-231, 1963.

SALIBE, A.B; JAEHN, A.. Reação de doze porta-enxertos cítricos ao nematóide Tylenchulus semipenetrans. Nematologia Brasileira, v.20, n.1, p.44-52, 1996.

SALVA, R.A., ROBERTO, S.R.; CARLOS, E.F. Situação da clorose variegada dos citros do Estado de São Paulo. Laranja, Cordeirópolis, v. 16, n.2, p.155-164, 1995.

SCORA, R. W Biochemistry, taxonomy and evolution of modern cultivated citrus. Proceedings of the International Society of Citriculture, v.1 277-289, 1988.

SCORA, R.W; KUMAMOTO, J. Chemotaxonomy of genus Citrus. In: Waterman P. G.; Grundon, M.F. (eds). Chemistry and Chemical taxonomy of the rutales. Academic Press. London. pp.343-351, 1983.

SHERALD, J.L.; LEI, J.D. Evaluation of a rapid ELISA test kit for detection of Xylella fastidiosa in landscape trees. Plant Disease, v.75, n.2, 1991.

SHERALD, J.L.; KOSTKA, S. J. Bacterial leaf scorch of landscape trees caused by Xylella fastidiosa. Journal Arboric, v.18, p.57-63, 1992. 
SOUZA, P.S.; DONADIO, L.C.; JAIMEZ, E.P.G. Avaliação de alguns genótipos de citros em relação a clorose variegada dos citros (CVC). Revista Brasileira de Fruticultura, v.22, n.2,p.148-152, 2000.

SUGIMORI, M.H.; PARADELA FILHO, 0.; RIBEIRO, I.J.A.; LARANJEIRA, F.F.; GARCIA Jr. A.; MARTINS, A.L.M. Estudo de transmissão do agente da CVC por semente. Summa Phytopathologica, v.21 n.1, p.58, 1995. Congresso Paulista de Fitopatologia, Piracicaba, 1995 - Resumo

SWINGLE, W.T.; REECE, P.C. The botany of citrus and its wild relatives. In; Reuther, W.; Webber, H.J.; Batchelor, L.D. (eds) The Citrus industry, Berkeley, University of California. p.190-430, 1967.

SWINGLE, W.T. The botany of Citrus and its wild relatives of the orange subfamily. In: Webber, H.J.; Batchelor, L.D. (eds). The Citrus Industry, Berkeley, University of California, p.129-474. 1943.

TANAKA, T. Species problem in citrus. A critical study of wild and cultivated units of citrus, based upon field studies in their native homes. Ueno, Tokio: Japanese Society for promotion of Science, 1954. Cap.11, p.58-68: Citrus distribution with reference to Tanaka line.

TEÓFILO SOBRINHO, J. et al. Comparativo de cinco densidades de plantio para laranjeira Valencia enxertada em trifoliata limeira. In: Congresso Brasileiro de Fruticultura 7,1984, Florianópolis. Anais...Florianópotis: Sociedade brasileira de Fruticultura, 1984. v.2, p.612-21.

TUBELIS, A. Difusão da clorose em pomares de São Paulo e Minas Gerais. Informativo Coopercitrus, p.24-31, 1992.

TUBELIS, A.; BARROS, J.C.S.M. \& LEITE, R.M.V.B.C. Difusão da clorose variegada dos citros em pomares comerciais de laranja no Brasil. Laranja, Cordeirópolis, v.14, n.1, p. 239-254, 1993a.

TUBELIS, A., RODRIQUES NETO, J. \& BERETTA, M. J. G. Primeira constatação da anomalia clorose variegada dos citros no Estado de Goiás. Summa Phytopathologica, v.19, n.1, p. 46, 1993 b. 
VITTI, G. C., MARCHI, R.J. BORELLA, M.L., VAZ FILHO, D. Estudo de prováveis desequilíbrios nutricionais em pomares cítricos no município de Colina-SP. Jaboticabal: FCAV, UNESP, 1989, 12p. (mimeografado).

WELLS, J.M.; WEAVER, D.J.; RAJU, B.C. Distribution of rickettisia-like bacteria in peach, and their occurrence in plum, cherry, and some perennial weeds. Phytopathology, v.70, p. 817-820, 1980.

WELLS, J.M., RAJU, B.C., NYIAND, G., and LOWE, S.K. Medium for isolation and growth of bacteria associated with plum leaf scald and phony peach diseases. Applied Environment Microbiology, v.42, p.357-363, 1981.

WELLS, J.M., RAJU, B.C., HUNG, WY., WCISBURG, W.G., MANDELCO-PAUL, L.; BRENNER, D.G. Xylella fastidiosa gen. nov., sp. nov.: gram negative, xylemlimited, fastidious plant bacteria related to Xanthomonas spp. International Journal Systematic Bacteriology, v.37, v.136-143, 1987

YORINORI, M.A.; FUNADA, C.K.; JR, R.P. LEITE. Associação de Xylella fastidiosa com sementes de cafeeiro. p.214 In: XXIII Congresso Paulista de Fitopatologia. Programas e resumo, Campinas, Brasil. 2000.

ZAR, J.H. Biostatistical Analisys. Englewood Cliffs, Prentice Hall, $2^{a}$ ed, 1984.718p. 